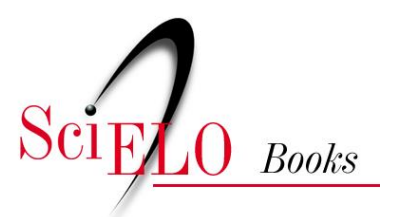

กิ

FIOCRUZ

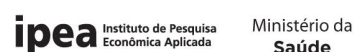

Secretaria de Assuntos Estratégicos

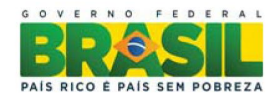

\title{
Formação, mercado de trabalho e regulação da força de trabalho em saúde no Brasil
}

\author{
Mario Roberto Dal Poz \\ Celia Regina Pierantoni \\ Sábado Girardi
}

\section{SciELO Books / SciELO Livros / SciELO Libros}

POZ, MRD., PERANTONI, CR., and GIRARDI, S. Formação, mercado de trabalho e regulação da força de trabalho em saúde no Brasil. In FUNDAÇÃO OSWALDO CRUZ. A saúde no Brasil em 2030 - prospecção estratégica do sistema de saúde brasileiro: organização e gestão do sistema de saúde [online]. Rio de Janeiro: Fiocruz/Ipea/Ministério da Saúde/Secretaria de Assuntos Estratégicos da Presidência da República, 2013. Vol. 3. pp. 187-233. ISBN 978-85-8110-017-3. Available from SciELO Books < http://books.scielo.org>.

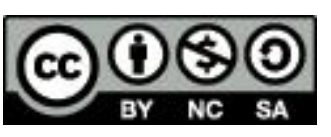

All the contents of this chapter, except where otherwise noted, is licensed under a Creative Commons Attribution-Non Commercial-ShareAlike 3.0 Unported.

Todo o conteúdo deste capítulo, exceto quando houver ressalva, é publicado sob a licença Creative Commons Atribuição Uso Não Comercial - Partilha nos Mesmos Termos 3.0 Não adaptada.

Todo el contenido de este capítulo, excepto donde se indique lo contrario, está bajo licencia de la licencia Creative Commons Reconocimento-NoComercial-CompartirIgual 3.0 Unported. 
Formação, Mercado de Trabalho e Regulação da Força de Trabalho em Saúde no Brasil 


\section{FORMAÇÃO, MERCADO DE TRABALHO E REGULAÇÃO DA FORÇA DE TRABALHO EM SAÚDE NO BRASIL}

Mario Roberto Dal Poz

Celia Regina Pierantoni

Sábado Girardi

\section{1 | INTRODUÇÃO}

A reconfiguração social do país com o surgimento de uma "nova classe média" (ou nova classe trabalhadora, conforme Souza, 2010), produto dos movimentos de redistribuição de renda, da reestruturação produtiva e do combate à pobreza nacional e internacional, incorpora valores e define metas relacionadas ao consumo de bens, serviços, tecnologia e saúde, entre outros e também metas relacionadas às pessoas envolvidas na produção desses bens, serviços e tecnologias. A importância crítica da força de trabalho em saúde nos sistemas de saúde que apresentam bom desempenho é hoje tema de consenso entre formuladores de políticas públicas, particularmente as que visam à equidade na distribuição como a melhoria da qualidade dessa força de trabalho em todos os níveis.

Outro consenso, para falarmos de futuro, diz respeito à necessidade de inovação dos arranjos e instituições do regime jurídico de propriedade da produção desses bens e serviços — regimes que preencham a lacuna nas formas da propriedade estatal (da comunidade política), a exemplo das Fundações Estatais de Direito Privado, e, complementares a estas e à propriedade privada (dos indivíduos e dos mercados). Assim também o futuro desvelará, com mais força ainda, os "novos" arranjos de vinculação do trabalho e das relações de trabalho nas organizações de saúde. Apesar da antiguidade da prática ainda está para surgir um novo direito do trabalho que supere a hegemonia do emprego típico (o vínculo de trabalho heterônomo consubstanciado no emprego assalariado) como forma predominante do trabalho livre em nossas sociedades. Também na saúde, quer dizer, no trabalho em saúde, as formas cooperativas e associativas do autoemprego decente, distintas dos arranjos precários, tenderão a ganhar ademais da licitude e base ética que já possuem, legalidade e, mais ainda, tenderão a adquirir proteção social e previdenciária completa a partir de novos pactos de financiamento de 
proteção do trabalho entre os atores protagonistas das relações de trabalho. Ou então, para confirmar o vaticínio de Bourdieu, aprofundaremos definitivamente na "precariedade" por ele anunciada como prenúncio desse nosso justo inaugurado milênio.

A mudança dos padrões de saúde, movimentos de população, fluxos financeiros, avanços tecnológicos e de telecomunicações e a difusão do conhecimento em saúde e as inovações dos sistemas de saúde, no Brasil e também globalmente, requerem uma força de trabalho em saúde mais afinada com as necessidades de saúde a e compatíveis com a organização de serviços de saúde ao longo do tempo. Dessa forma as bases técnicas e sociais desenvolvidas no trabalho em saúde representam, para além de um conjunto de transformações cotidianamente relacionadas com a história biomédica, um processo mais ampliado de transformações da sociedade relacionado com a estrutura social, a organização política e cultural.

O setor de serviços de saúde tem sido caracterizado por uma série de traços estruturais, mais ou menos interligados. Em primeiro lugar, é um setor constituído por atividades eminentemente intensivas em mão de obra, a despeito mesmo do intenso dinamismo com que novas tecnologias são crescentemente incorporadas às práticas do setor. Admitimos, ao contrário do que observamos em outros setores da atividade econômica, que a introdução de novas tecnologias na saúde — sejam novos produtos, instrumentos e equipamentos propedêuticos e terapêuticos, sejam novos processos - sem substituir as tecnologias preexistentes, na maioria das vezes, acrescenta-se a elas e, ao contrário de economizar mão de obra, exigem novas qualificações para sua operação, fazendo crescer, no final das contas, a demanda efetiva por força de trabalho. Entre nós, uma série de autores já chamou a atenção para este fenômeno (GIRARDI, 1999).

Duas implicações principais podem ser atribuídas a esta associação paradoxal entre intensidade do uso de trabalho e incorporação tecnológica. Por um lado, de forma negativa, ela estaria na raiz de certa intratabilidade da tendência ao crescimento dos gastos com a saúde. Disto não trataremos. Em contrapartida, em se mantendo inalterados os fatores que atualmente estimulam o crescimento da demanda pelos serviços de saúde (especialmente o envelhecimento das populações e o aumento da eficácia das tecnologias médicas) os serviços de saúde tenderiam a aumentar seu peso, relativamente a outros setores da economia, na absorção da população economicamente ativa dos países. Neste contexto, o emprego de força de trabalho no setor poderia cumprir um papel adicional às dimensões assistenciais curativas, preventivas, reparadoras ou de promoção da saúde, não importa, para as quais eles estariam precipuamente voltados. $\mathrm{Na}$ verdade, da perspectiva da política social ou da macroeconomia, o setor poderia ter um potencial suplementar de ser capaz de "amortecer", através da geração de emprego e renda, o impacto social das tendências de crescimento do desemprego nas sociedades modernas. 
Um segundo traço distintivo das atividades de saúde, mais ou menos observado em todos os países, é a forte presença de ocupações regulamentadas e a vulnerabilidade da gestão setorial em relação às normas do "mundo das profissões". Desse segundo aspecto decorre que a regulação de grande parte da força de trabalho do setor escapa, em importantes aspectos quantitativos e qualitativos, tanto aos mecanismos autorreguladores dos mercados ${ }^{1}$ como aos desideratos da gerência organizacional (ou da burocracia) do setor. O aparato corporativo profissional, as universidades e o sistema educativo jogam papel decisivo na definição dos níveis da oferta e padrões de qualidade da força de trabalho do setor.

Um terceiro traço distintivo do setor saúde, com relação a outros setores econômicos, é a sua peculiar inserção no sistema econômico. A alta repercussão social dos serviços prestados pelo setor, juntamente com seu peculiar dinamismo no que diz respeito à incorporação científico-tecnológica ao processo de trabalho (conforme comentado), insere o setor de serviços de saúde numa zona de fronteiras amplas e pouco demarcadas "entre os sistemas de bem-estar social e os sistemas de inovação” (CAMPOS e ALBUQUERQUE, 1998:15). As instituições que respondem a estes dois sistemas (a saúde pública, a seguridade social, as universidades e institutos de pesquisa, os laboratórios científicos, a rede de cientistas, entre outras) também jogam um papel importante na definição das regras de incorporação de trabalho ao setor. E mais uma vez aqui podemos dizer que estes são dois sistemas (ou para usarmos o termo de Albuquerque, "duas construções institucionais") que, igualmente ao caso das profissões, se constituíram no sentido de superar as limitações da regulação de mercado. Reconhecemos sobejamente, em ambos os casos, os limites dos mecanismos dos mercados autorreguláveis, quer para atingirem os objetivos de equidade inscritos nos sistemas de bem-estar social, quer para obterem os graus de eficiência de largo prazo, propugnados pelos sistemas de inovação técnica.

Finalmente, um quarto traço estrutural das atividades do setor de serviços de saúde estaria relacionado com a preponderância da força de trabalho feminina, fenômeno observado em todos os países, especialmente naquelas atividades

1 Na verdade, a chamada a autorregulação dos mercados estaria inibida em função de outras características peculiares ao setor. O cuidado de saúde não é um bem econômico típico e o setor saúde pode ser caracterizado pela existência generalizada de "falhas de mercado". Na literatura econômica, uma série de condições devem ser preenchidas para que a autorregulação dos mercados funcionem como mecanismo ideal de alocação eficiente de recursos. Em primeiro lugar, é necessária a existência permanente de quantidades expressivas de produtores e consumidores e que a entrada nos mercados seja livre. Em segundo lugar, os bens e serviços produzidos devem ser homogêneos e ambas as partes, produtores e consumidores devem possuir informações suficientes a respeito dos preços e qualidades entre escolhas alternativas. Em terceiro lugar, não deve haver maiores externalidades (ou efeitos de vizinhança) na produção e no consumo. Nenhuma dessas condições, conforme é amplamente reconhecido, se verificam na produção de serviços de saúde. Em primeiro lugar, o forte profissionalismo do setor coloca sérias barreiras à entrada de parcela considerável da força de trabalho setorial nos mercados. Noutras palavras, o número de provedores é regulado desde fora dos mercados, pelo sistema educacional e pela corporações profissionais. Em segundo lugar, o produto dos serviços de saúde é tudo que se quer que seja menos homogêneo. O aforismo "cada caso é um caso", extremamente utilizado para a descrição de situações médicas, apesar de que seja empregado às vezes de maneira abusiva, não é um completo exagero. 
que envolvem o trato e o cuidado das pessoas, como a enfermagem. Com efeito, conforme veremos para o caso do Brasil, o setor de serviços de saúde é o que mostra a maior participação de mulheres na composição do emprego dentre todos os setores de atividade econômica.

Admitimos também, de forma paradoxal, o caráter cumulativo e não substitutivo da maior parte das tecnologias na área da saúde, o que se constitui num verdadeiro desafio para fazer previsões do que será essa força de trabalho em saúde no futuro - cuja contradição, pouco temos explorado. Grande parte dessa "insubstituibilidade" deriva do poder da profissão médica, do poder de deter na forma da propriedade privada legalmente constituída, certos atos - nos termos de Illich, por exemplo, aqui temos o verdadeiro exemplo de uma tecnologia contraproducente (como mostra Nogueira, 2003, por exemplo). O trabalho do médico constitui-se como expropriação da saúde e uma tirania contra a saúde como autocuidado, como possibilidade das pessoas elas mesmas se enfrentarem, na cultura e na técnica, perdidas no domínio da expertise heteronomificada, das experiências da dor e da morte (NOGUEIRA, 2003).

Os trabalhadores em saúde compõem um conjunto grande e diverso de profissionais e técnicos influenciados por diferentes sistemas de formulação de políticas com autonomia, direcionalidade e centralizações próprias, não reguladas estritamente pelas políticas setoriais, pouco sensíveis, conforme dissemos, à regulação de mercado, às leis da oferta e da procura e dos preços. O processo de trabalho em saúde depende assim de múltiplas e diferenciadas dimensões e fatores que cercam o financiamento, a organização e o desempenho dos sistemas de saúde. Mais ainda, profissionais com especificidades e habilidades distintas incorporadas no processo de trabalho e no desenvolvimento de um trabalho com características cada vez mais coletivas em saúde.

Por outra via, o mercado de trabalho em saúde é dependente de um continente expressivo de trabalhadores sem formação ou habilitação específica para o trabalho a ser desenvolvido no setor, desempenhando funções auxiliares em diversos planos laborais, por exemplo, administrativas, legais, o que acentua as diferenças no plano da técnica e da responsabilidade pelo trabalho executado.

Essa composição múltipla é também acrescida de outros técnicos e profissionais, de áreas não especificamente correlacionadas com a prestação direta de serviços de saúde. Essa força de trabalho é cada vez mais incorporada ao sistema de saúde em decorrência de fatores como o desenvolvimento tecnológico (ex. informática), da apuração de técnicas para aferimento dessa prestação viabilizadas por sistemas de controle e de custos (ex. economistas e administradores especializados) e do aprimoramento e desenvolvimento de novas áreas (ex. engenharia clínica), entre outras. 
Desta forma a abordagem do tema "força de trabalho em saúde" será feita através de três vertentes: o mercado de trabalho em saúde e o desenvolvimento social; a formação e qualificação para o trabalho em saúde e; profissões e regulação profissional.

\section{MERCADO DE TRABALHO EM SAÚDE E DESENVOLVIMENTO SOCIAL}

O setor saúde foi o que mais ampliou a oferta de emprego na última década, continuando a ser trabalho-intensivo. No final da década passada, com a forte expansão do mercado de trabalho em saúde via PSF e atenção primária à saúde com prioridade para regiões menos assistidas (Nordeste> Centro-Oeste> Norte), utilizando médicos, enfermeiros, odontólogos, auxiliares de enfermagem e agentes de saúde comunitários.

A Tabela 1 sintetiza a mensuração do macrosetor Saúde segundo setores de atividade e segmentos ocupacionais. Primeiramente, os itens I.a, III, IV, V e VI são de dimensionamento direto através dos setores de atividade, isto é, via CNAE. Em outras palavras, a totalidade de trabalhadores no núcleo do setor (atividades de atendimento hospitalar, ambulatorial, SADT, etc.), nas atividades industriais, de comercialização e financeiras vinculadas à saúde, e nas atividades de saneamento, é automaticamente contada. Em seguida, os itens II e VII são mensurados pelo cruzamento entre atividade econômica e ocupação, o que corresponde ao total de profissionais de saúde (A) nas atividades complementares (A em II) e nos demais setores (A em VII). Uma exceção é feita ao item II, pois as atividades complementares de assistência social e psicossocial e seguridade social obrigatória, também entram em sua totalidade, isto é, sem lançar mão da proxy de profissões. Finalmente, o número de outros trabalhadores no núcleo público do setor (B em I.b) deve ser estimado seguindo a mesma proporção encontrada no núcleo privado do setor (B em I.a), lembrando que apenas para análises com a PNAD. Outros trabalhadores em atividades complementares e demais setores vinculados à prestação de saúde não são contados. 
Tabela 01. Representação da mensuração do macro setor Saúde, Brasil

\begin{tabular}{|c|c|c|c|}
\hline & \multicolumn{2}{|c|}{ Segmentos ocupacionais } \\
\hline & & $\begin{array}{l}\text { (A) } \\
\text { Profissionais }\end{array}$ & $\begin{array}{l}\text { (B) Outros } \\
\text { trabalhadores }\end{array}$ \\
\hline \multirow{8}{*}{$\begin{array}{l}\text { Setores de } \\
\text { atividade }\end{array}$} & I.a. Núcleo do setor (Saúde Humana) & la. & la. \\
\hline & $\begin{array}{l}\text { I.b. Núcleo do setor (Administração } \\
\text { Pública) }\end{array}$ & Ib. & $\begin{array}{l}\text { B em Ib. } \\
\text { B em la. }\end{array}$ \\
\hline & II. Atividades complementares & A em II* & $A^{* *}$ \\
\hline & III. Atividades industriais & III & III \\
\hline & IV. Comercialização & IV & IV \\
\hline & V. Atividades financeiras & V & V \\
\hline & VI. Atividades de saneamento & VI & VI \\
\hline & VII. Demais setores & A em VII & \\
\hline
\end{tabular}

*Exceto assistência social e psicossocial e seguridade social obrigatória, considerados em sua totalidade.

**Exceto Ensino e P\&D e atividades de regulação.

A Tabela 2 apresenta uma aplicação da síntese de mensuração para a PNAD de 2008. Representando 5,9\% do total de ocupados no período, o macro setor saúde somava em torno de 5.456 .010 pessoas, sendo que 2.763.506 de profissionais de saúde e 2.692.504 de outros trabalhadores de saúde. O núcleo do setor referente à seção Saúde Humana registrou uma razão de 1,5 profissionais de saúde para cada outro trabalhador (1.734.152 para 1.118.313), destacando a forte profissionalização do setor. Utilizando-se da mesma razão para estimar o número de outros trabalhadores na seção de Administração Pública, verificou-se um total de 170.592 ocupados para 480.373 profissionais. Além do núcleo do setor, as atividades de comercialização foram as que mostraram o maior volume de ocupados (719.949), seguidas de atividades de saneamento (381.704), demais setores (307.510), atividades industriais (255.860), atividades financeiras (172.726) e atividades complementares (114.831). 
Tabela 02. Dimensionamento do macro setor saúde segundo setores de atividades e segmentos ocupacionais (profissionais e outros trabalhadores de saúde) — Brasil, 2008

\begin{tabular}{l|r|r|r}
\hline \multirow{2}{*}{\multicolumn{1}{c|}{ Setores de atividade }} & \multicolumn{2}{c|}{ Segmentos ocupacionais } & \multirow{2}{*}{ Total } \\
\cline { 2 - 3 } & Profissionais & $\begin{array}{c}\text { Outros } \\
\text { trabalhadores }\end{array}$ & \\
\hline Núcleo do setor (saúde humana) & 1.734 .152 & 1.118 .313 & 2.852 .465 \\
\hline Núcleo do setor (administração pública) & 480.373 & $170.592^{*}$ & 650.965 \\
\hline Atividades complementares & 114.831 & $503.916^{* *}$ & 114.831 \\
\hline Atividades industriais & 60.256 & 195.604 & 255.860 \\
\hline Comercialização & 55.222 & 664.727 & 719.949 \\
\hline Atividades financeiras & 8.837 & 163.889 & 172.726 \\
\hline Atividades de saneamento & 2.325 & 379.379 & 381.704 \\
\hline Demais setores & 307.510 & & 307.510 \\
\hline Total macro setor & $\mathbf{2 . 7 6 3 . 5 0 6}$ & $\mathbf{2 . 6 9 2 . 5 0 4}$ & $\mathbf{5 . 4 5 6 . 0 1 0}$ \\
\hline Percentual no total da economia & $\mathbf{2 , 9 9 \%}$ & $\mathbf{2 , 9 1 \%}$ & $\mathbf{5 , 9 0 \%}$ \\
\hline
\end{tabular}

Fonte: IBGE. Pesquisa Nacional por Amostra de Domicílios — PNAD.

*Valor estimado.

**Exclusive Ensino e P\&D.

A Tabela 3, por sua vez, apresenta a mensuração do macro setor segundo número de empregos formais registrados na RAIS em dezembro de 2008. O total do setor representava $11,01 \%$ do mercado formal brasileiro, maior que o percentual de ocupados no setor em relação ao total da economia, como observado pela PNAD, o que destaca a importância do setor para o mercado formal brasileiro. Como o número de outros trabalhadores de saúde no setor Administração Pública não foi estimado, é preciso destacar que este percentual pode ser ainda maior. Além do núcleo do setor, o maior volume de número de empregos foi encontrado em atividades de comercialização (467.853), seguidas de profissionais em outros setores (302.750), atividades complementares (278.281), saneamento (254.760), indústria (135.429) e atividades de financiamento (71.165). 
Tabela 03. Número de empregos no macro setor Saúde segundo setor de atividade — Brasil, 2008

\begin{tabular}{|c|c|}
\hline Classe CNAE & Empregos \\
\hline I - Núcleo do setor (Saúde Humana) & 2.835 .488 \\
\hline I.a-Serviços privados & 1.282 .526 \\
\hline Atendimento hospitalar & 800.762 \\
\hline Atendimento a urgências e emergências & 2.010 \\
\hline Serviços de remoção de pacientes & 1.113 \\
\hline Atenção ambulatorial executada por médicos e odontólogos & 182.806 \\
\hline Serviços de complementação diagnóstica e terapêutica & 121.639 \\
\hline Outros profissionais da saúde & 66.505 \\
\hline Atividades de apoio à gestão de saúde & 17.948 \\
\hline Outras atividades relacionadas com atenção à saúde & 85.379 \\
\hline Atividades veterinárias & 4.364 \\
\hline I.b - Núcleo do setor (Administração Pública) & 1.252 .962 \\
\hline Profissionais de saúde em serviços públicos & 944.121 \\
\hline Demais trabalhadores em serviços públicos de saúde* & 608.841 \\
\hline II - Atividades Complementares & 278.281 \\
\hline Atividades de assistência social e psicossocial & 88.662 \\
\hline Seguridade social obrigatória & 32.402 \\
\hline Profissionais de saúde em Regulação de serviços de saúde & 45.275 \\
\hline Profissionais de saúde em Ensino e Pesquisa \& Desenvolvimento em saúde & 111.942 \\
\hline III - Atividades Industriais & 135.429 \\
\hline Fabricação de produtos farmoquímicos & 5.906 \\
\hline Fabricação de medicamentos para uso humano & 73.655 \\
\hline Fabricação de medicamentos para uso veterinário & 7.486 \\
\hline Fabricação de preparações farmacêuticas & 3.808 \\
\hline Fabricação de instrumentos e materiais para uso médico e odontológico e de artigos ópticos & 41.252 \\
\hline Manutenção e reparação de equipamentos e produtos não especificados anteriormente & 3.322 \\
\hline IV - Atividades de comercialização & 467.853 \\
\hline Comércio atacadista e varejista de produtos farmacêuticos & 368.852 \\
\hline Comércio atacadista e varejista de produtos médicos, odontológicos, ortopédicos e ópticos & 99.001 \\
\hline V-Atividades de financiamento & 71.165 \\
\hline Seguros-saúde & 5.411 \\
\hline Planos de saúde & 65.754 \\
\hline
\end{tabular}




\begin{tabular}{|r|r}
\multicolumn{1}{c|}{ Classe CNAE } & Empregos \\
\hline VI - Atividades de saneamento & 254.760 \\
\hline Captação, tratamento e distribuição de água & 118.965 \\
\hline Atividades relacionadas a esgoto & 36.178 \\
\hline Coleta, tratamento e disposição de resíduos & 99.017 \\
\hline VII - Profissionais de saúde em outros setores & 302.750 \\
\hline № de empregos no macro setor Saúde & 4.345 .726 \\
\hline Percentual em relação ao total da economia & $11,01 \%$ \\
\hline
\end{tabular}

Fonte: MTE. Relação Anual de Informações Sociais - RAIS.

*Valor estimado.

As Tabelas 4 e 5 apresentam uma breve análise dos empregos formais de profissões e ocupações de saúde. No cômputo geral, elas somam 2.204.173 empregos, sendo 1.901.423 nas atividades componentes do macro setor (núcleo, complementares, indústria, comércio, financiamento e saneamento) e 302.750 nos demais setores. Aquelas que representam os maiores contingentes de emprego são os auxiliares de enfermagem (355.824), médicos (240.428), técnicos em enfermagem (239.904), agentes comunitários de saúde (237.548) e enfermeiros (129.905).

Do ponto de vista salarial, os melhores salários médios em 2008 foram reservados aos pesquisadores em ciências da saúde, com média de $R \$ 5.667,42$, seguidos de médicos ( $R \$ 3.858,68)$, veterinários e zootecnistas ( $R \$ 3.718,43)$ e professores em ciências da saúde ( $\mathrm{R} \$ 3.230,36)$. os menores salários praticados no período foram reservados aos cuidadores de idosos ( $R \$ 616,98)$, atendentes de farmácia ( $R \$ 725,33)$, técnicos em odontologia ( $R \$ 770,19)$, agentes comunitários da saúde $(\mathrm{R} \$ 796,89)$ e auxiliares de laboratório da saúde (R\$ 835,70).

O salário por hora de trabalho das ocupações de nível superior variou entre $R \$ 36,61$, observado entre médicos, e $R \$ 13,87$, entre nutricionistas. Já o salário por hora de trabalho das ocupações de nível médio, técnico e elementar variou de $\mathrm{R} \$ 13,43$ entre técnicos em equipamentos médicos e odontológicos, e R\$3,69 entre cuidadores de idosos. A categoria de diretores e gerentes em serviços de saúde registrou média de $\mathrm{R} \$ 23,19$ por hora de trabalho. Quanto à razão salarial entre as médias do saláriohora de uma ocupação de saúde e a média do salário-hora de médicos, observou-se que as melhores razões foram as dos pesquisadores e professores em ciências da saúde, com 96,5\% do salário-hora de médicos, seguidos de veterinários e zootecnistas, $78,2 \%$, diretores e gerentes de serviços de saúde, $63,3 \%$, e cirurgiões dentistas, $59,1 \%$. As menores razões registradas foram as de cuidadores de idosos, 10,1\%, atendentes de farmácia, 11,5\%, e auxiliares de laboratório de saúde e agentes comunitários de saúde, ambos com $14 \%$. 
Tabela 04. Número de empregos formais por ocupação de saúde - Brasil, dezembro de 2008

\begin{tabular}{|c|c|c|c|}
\hline Ocupação & $\begin{array}{l}\text { Empregos no } \\
\text { macro setor }\end{array}$ & $\begin{array}{l}\text { Empregos em } \\
\text { outros setores }\end{array}$ & Total \\
\hline Médico & 240.428 & 21.130 & 261.558 \\
\hline Cirurgião dentista & 46.629 & 7.732 & 54.361 \\
\hline Veterinário e Zootecnista & 11.998 & 4.778 & 16.776 \\
\hline Farmacêutico & 70.674 & 4.931 & 75.605 \\
\hline Enfermeiro & 129.905 & 10.520 & 140.425 \\
\hline Fisioterapeuta & 19.121 & 5.108 & 24.229 \\
\hline Fonoaudiólogo & 5.922 & 2.639 & 8.561 \\
\hline Terapeuta Ocupacional & 3.091 & 1.345 & 4.436 \\
\hline Nutricionista & 12.918 & 10.191 & 23.109 \\
\hline Psicólogo e psicanalista & 24.023 & 9.942 & 33.965 \\
\hline Assistente social & 38.183 & 12.379 & 50.562 \\
\hline Biólogo & 11.521 & 1.821 & 13.342 \\
\hline Professor em ciências da saúde & 28.231 & 4.748 & 32.979 \\
\hline Pesquisadores em ciências da saúde & 2.362 & 118 & 2.480 \\
\hline Diretores e gerentes de serviços de saúde & 19.747 & 1.353 & 21.100 \\
\hline Técnico em enfermagem & 239.904 & 19.490 & 259.394 \\
\hline Auxiliar de Enfermagem & 355.824 & 31.265 & 387.089 \\
\hline Técnico em óptica e optometria e Ortoptista & 2.863 & 733 & 3.596 \\
\hline Técnicos de odontologia & 51.222 & 6.345 & 57.567 \\
\hline Técnico de ortopedia & 994 & 240 & 1.234 \\
\hline Técnico de imobilização ortopédica & 1.608 & 131 & 1.739 \\
\hline Técnicos em equipamentos médicos e odontológicos & 33.041 & 2.180 & 35.221 \\
\hline Técnicos e auxiliares técnicos em patologia clínica & 27.404 & 2.660 & 30.064 \\
\hline Técnico em histologia & 89 & 23 & 112 \\
\hline Técnicos em manipulação farmacêutica & 9.981 & 1.276 & 11.257 \\
\hline Técnico em segurança no trabalho & 5.224 & 50.185 & 55.409 \\
\hline Técnico manut. de equip. e inst. médico hospitalares & 545 & 291 & 836 \\
\hline Acupunturistas, podólogos, quiropraxistas e afins & 1.725 & 2.321 & 4.046 \\
\hline Agentes de saúde e do meio ambiente & 125.634 & 11.680 & 137.314 \\
\hline Agente comunitário de saúde e afins & 237.548 & 26.772 & 264.320 \\
\hline Auxiliares de laboratório de saúde & 65.974 & 17.391 & 83.365 \\
\hline Cuidador de idosos & 3.652 & 3.055 & 6.707 \\
\hline Total de empregos & 1.827 .985 & 274.773 & 2.102.758 \\
\hline
\end{tabular}

Fonte: MTE. Relação Anual de Informações Sociais - RAIS. 
Tabela 05. Salários médios, média de horas semanais de trabalho, média salarial por hora de trabalho e razão salarial de profissionais de saúde no mercado formal por ocupação - Brasil, dezembro de 2008

\begin{tabular}{|c|c|c|c|c|}
\hline Ocupação & $\begin{array}{c}\text { Salário } \\
\text { Médio (R\$) }\end{array}$ & $\begin{array}{c}\text { Média } \\
\text { de Horas } \\
\text { Semanais }\end{array}$ & $\begin{array}{c}\text { Média Salarial } \\
\text { por Hora de } \\
\text { Trabalho (R\$) }\end{array}$ & $\begin{array}{c}\text { Razão } \\
\text { Salarial* }\end{array}$ \\
\hline Médico & $3.858,68$ & 26,35 & 36,61 & 100,0 \\
\hline Cirurgião dentista & $2.532,28$ & 29,25 & 21,64 & 59,1 \\
\hline Veterinário e Zootecnista & $3.718,43$ & 32,47 & 28,63 & 78,2 \\
\hline Farmacêutico & $1.992,90$ & 39,44 & 12,63 & 34,5 \\
\hline Enfermeiro & $2.657,56$ & 36,81 & 18,05 & 49,3 \\
\hline Fisioterapeuta & $1.851,01$ & 31,40 & 14,74 & 40,3 \\
\hline Fonoaudiólogo & $1.805,13$ & 31,83 & 14,18 & 38,7 \\
\hline Terapeuta Ocupacional & $2.003,54$ & 30,97 & 16,17 & 44,2 \\
\hline Nutricionista & $2.006,48$ & 36,16 & 13,87 & 37,9 \\
\hline Psicólogo e psicanalista & $2.047,64$ & 33,40 & 15,33 & 41,9 \\
\hline Assistente social & $2.447,85$ & 35,53 & 17,22 & 47,0 \\
\hline Biólogo & $2.764,78$ & 35,01 & 19,74 & 53,9 \\
\hline Professor em ciências da saúde & $3.230,36$ & 22,85 & 35,34 & 96,5 \\
\hline Pesquisadores em ciências da saúde & $5.667,42$ & 40,10 & 35,33 & 96,5 \\
\hline Diretores e gerentes de serviços de saúde & $2.998,66$ & 32,33 & 23,19 & 63,3 \\
\hline Técnico em enfermagem & $1.109,70$ & 38,23 & 7,26 & 19,8 \\
\hline Auxiliar de Enfermagem & $1.161,28$ & 37,52 & 7,74 & 21,1 \\
\hline Técnico em óptica e optometria e Ortoptista & $1.486,45$ & 42,16 & 8,81 & 24,1 \\
\hline Técnicos de odontologia & 770,19 & 40,04 & 4,81 & 13,1 \\
\hline Técnico de ortopedia & $1.417,52$ & 39,47 & 8,98 & 24,5 \\
\hline Técnico de imobilização ortopédica & $1.010,58$ & 39,53 & 6,39 & 17,5 \\
\hline Técnicos em equipamentos médicos e odontológicos & $1.558,80$ & 29,01 & 13,43 & 36,7 \\
\hline Técnicos e auxiliares técnicos em patologia clínica & $1.230,69$ & 35,67 & 8,62 & 23,6 \\
\hline Técnico em histologia & $1.279,91$ & 36,40 & 8,79 & 24,0 \\
\hline Técnicos em manipulação farmacêutica & $1.108,06$ & 40,37 & 6,86 & 18,7 \\
\hline Técnico em segurança no trabalho & $1.678,97$ & 41,84 & 10,03 & 27,4 \\
\hline Técnico manut. de equip. e inst. médico hospitalares & $1.601,97$ & 41,86 & 9,57 & 26,1 \\
\hline Acupunturistas, podólogos, quiropraxistas e afins & $1.106,85$ & 39,09 & 7,08 & 19,3 \\
\hline Agentes de saúde e do meio ambiente & $1.431,01$ & 38,07 & 9,40 & 25,7 \\
\hline Agente comunitário de saúde e afins & 796,89 & 39,00 & 5,11 & 14,0 \\
\hline Auxiliares de laboratório de saúde & 835,70 & 40,66 & 5,14 & 14,0 \\
\hline Cuidador de idosos & 616,98 & 41,85 & 3,69 & 10,1 \\
\hline
\end{tabular}

Fonte: MTE. Relação Anual de Informações Sociais - RAIS. 
Em referência às especialidades médicas, muitos estudos têm apontado a escassez em algumas áreas nas diversas regiões do país. Em 2004, o Ministério da Saúde encomendou uma série de estudos com o objetivo de investigar as necessidades de profissionais de saúde no país para o estabelecimento de políticas regulatórias para a abertura de cursos de graduação em saúde e para especialização em serviços de saúde na modalidade Residência Médica.

Os estudos confirmaram uma importante transição sócia demográfica e epidemiológica no país com características marcadas por fortes contrastes regionais e municipais. Desta forma, pode-se verificar uma grande escassez de algumas especialidades em geral, e em particular de médicos especialistas de áreas relacionadas a este novo cenário e comparado com outros países, como EUA e Canadá.

Gráfico 01. Razão do número de médicos equivalente a 40 horas (FTE) por 100 mil habitantes Brasil, EUA, Canadá

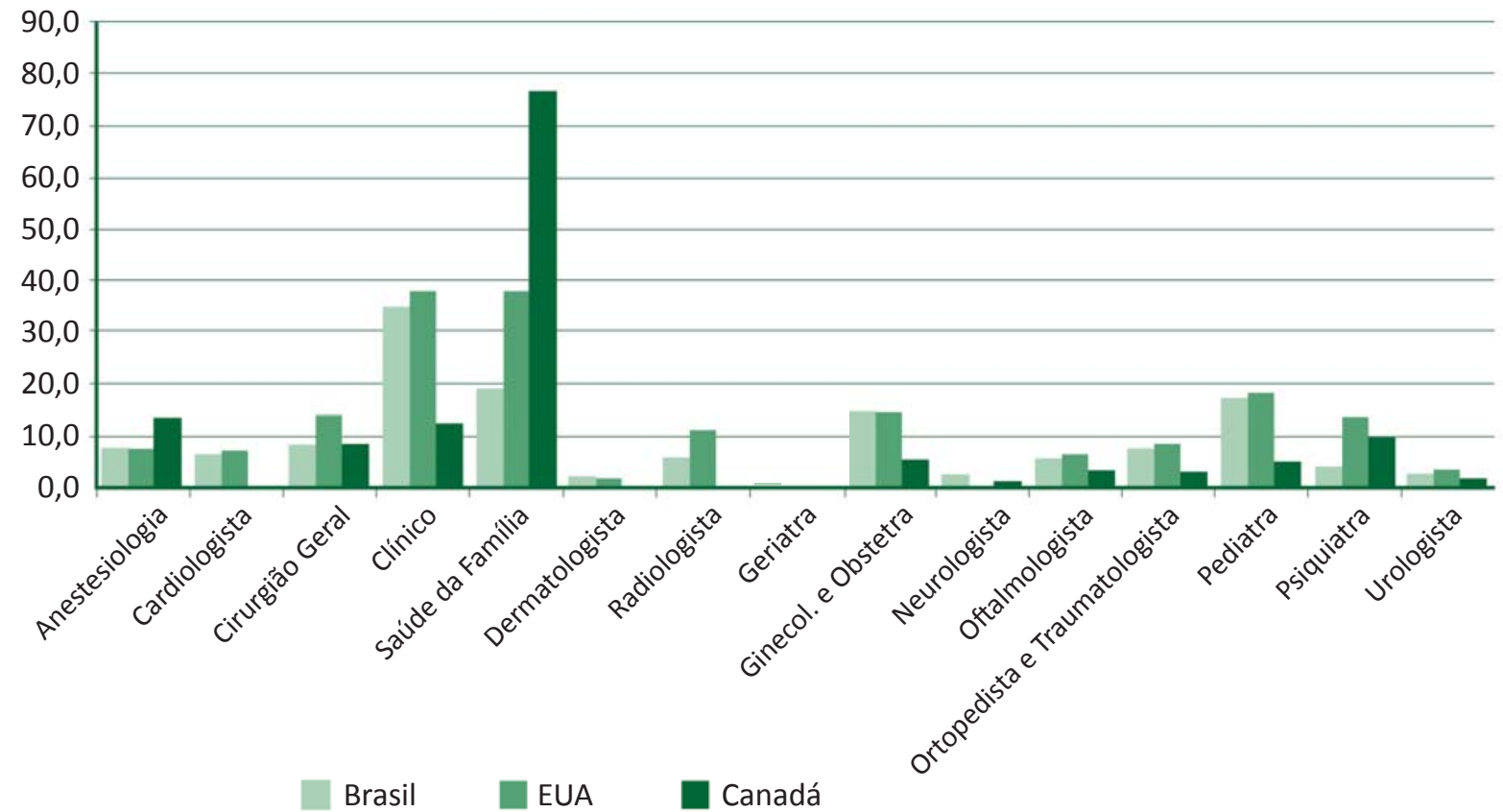

Fonte: Observatório de Recursos Humanos em Saúde - Estação de Pesquisas de Sinais de Mercado (EPSM/NESCON/FM/UFMG) a partir dos dados do Cadastro Nacional de Estabelecimentos de Saúde de dezembro de 2010 e Censo Demográfico de 2010, BUREAU OF HEALTH PROFESSIONS/HRSA. "The Physician Workforce: projections and research into current issues affecting supply and demand", 2008. e PITBLADO, R.; PONG, R. "Geographic Distribution of Physicians in Canada", 1999; 3. CANADIAN INSTITUTE FOR HEALTH INFORMATION. "National Physician Database, 2008-2009", 2010.

Considerando, por exemplo, a tendência de aumento da expectativa de vida da população, do crescente sucesso das terapêuticas contra o câncer, da necessidade de realização de diagnóstico precoce para esta patologia, observou-se uma grande desigualdade na distribuição de oncologistas, radioterapeutas e patologistas 
clínicos entre as regiões do país. E ainda, com o aumento da expectativa de vida da população brasileira e, assim, a proporção de idosos, os estudos mostraram que há um pequeno número de geriatras em todas as regiões.

Nestes estudos, verificou-se a falta de médicos especialistas em outras áreas, tais como:

- Uma relativa disponibilidade de equipamentos de imagem, por exemplo, radiológicos e ultrassonográficos, em contraste com a escassez nacional de radiologistas e ultrassonografistas, sendo a situação mais grave na região Norte, independente do porte do município;

- Carências de médicos intensivistas, e da mesma forma de leitos de UTI, embora estes cresçam significativamente com o tamanho da população dos municípios em todas as regiões;

- Mesmo nos lugares onde traumatologistas e neurocirurgiões são mais disponíveis, a carência destes especialistas ainda é a regra como em todo o país, a despeito do grande crescimento da morbimortalidade por causas externas;

- A disponibilidade de gineco-obstetras foi considerada relativamente adequada na maioria dos municípios e regiões do país. Ainda assim, a disponibilidade deste profissional também cresce de modo consistente dos municípios de menor porte para os de maior porte em todas as regiões do país;

- Em meio a tantas carências, a disponibilidade de pediatras aparece como uma das menos problemáticas no país, considerando a proporção de crianças na população e sua tendência à redução.

De maneira geral, exceção feita para os ginecologistas e pediatras, estes estudos concluíram que há carência de médicos gerais e especialistas, que surpreende não só pela magnitude, mas também por sua abrangência no território nacional, sugerindo a necessidade de dispositivos potentes para incentivar e orientara formação, inserção e fixação destes profissionais no SUS. (GIRARDI, 2009) 


\section{3 | FORMAÇÃO E QUALIFICAÇÃO PARA O TRABALHO EM SAÚDE}

O sistema de ensino superior no Brasil é predominantemente privado (entre $70 \%$ e 80\%). A predominância de instituições privadas também é observada na área da saúde (PIERANTONI et al., 2006, 2012). Em algumas áreas observa-se uma participação dominada por esse setor, como, por exemplo, biomedicina, fisioterapia, enfermagem, psicologia e nutrição. Em seis dos 14 cursos da área da saúde, o setor público apresenta taxa superior à média nacional de 21,8\% das matrículas. Em medicina, as matrículas do setor público superaram as do setor privado em 2004, mas, a partir de 2006, o setor privado correspondeu a mais de 50\% das matrículas.

A demanda pelos cursos de saúde permanece elevada, especialmente no setor público, no qual a relação candidato/vaga é fortemente positiva (16,2 contra 1,9 no setor privado). Para o curso de medicina, em 2008, a relação foi de 40,4 candidatos por vaga nas instituições públicas contra 10,8 nas privadas.

O aumento de egressos nas 14 áreas da saúde, cotejado com as demandas específicas das populações dos estados e das regiões, indicam diferenças regionais consideráveis na relação egresso/habitante. As regiões Sul e Sudeste apresentam os melhores índices na maioria dos casos e as regiões Norte e Nordeste os piores (PIERANTONI et al, 2006, 2012)

De 1991 a 2008 o número de cursos na área aumentou 458\%. Os cursos que mais cresceram foram ciências biológicas (649\%), nutrição (658\%) e fisioterapia (892\%), e os que menos cresceram foram medicina e odontologia (121\% e 137\%, respectivamente). (PIERANTONI et al, 2012).

As mulheres são maioria em todos os cursos da área da saúde, exceto em educação física e entre os concluintes da medicina. Porém, em 2007, as mulheres passaram a ser maioria também entre os ingressantes $(56,3 \%)$ e os concluintes $(54,7 \%)$ dos cursos de medicina. Em fonoaudiologia, serviço social, terapia ocupacional e nutrição as mulheres representam mais de 90\% dos estudantes. Em quase todos os cursos não se observa diferença estatisticamente significativa entre o gênero de ingressantes e concluintes, indicando uma estabilidade do aumento da participação feminina nos cursos da área.

Os estudantes com renda familiar de até três salários mínimos são em maior número no curso de enfermagem se comparado com os cursos de medicina e odontologia. A menor participação de estudantes nessa faixa de renda é observada entre os ingressantes dos cursos de medicina. Entre os concluintes, em 2004, o menor percentual era observado nos cursos de odontologia. (PIERANTONI et al, 2006, 2012). 


\section{1 | Tendências da Formação em Medicina, Odontologia e Enfermagem}

\subsection{1 | Medicina}

A curva de evolução do número de cursos de graduação em medicina no Brasil, conforme gráfico 2, indica um crescimento constante das variáveis segundo a natureza jurídica. No ano de 2000 existiam mais cursos públicos que privados; a partir de 2006 o número de cursos privados ultrapassa o de públicos e, embora na esfera pública o aumento do número de cursos também tenha ocorrido ( $\mathrm{n}=23 \%)$, o de natureza privada cresceu três vezes mais no mesmo período ( $\mathrm{n}=149 \%)$.

Gráfico 02. Cursos de Graduação em Medicina segundo Natureza Jurídica. Brasil 2000-2011

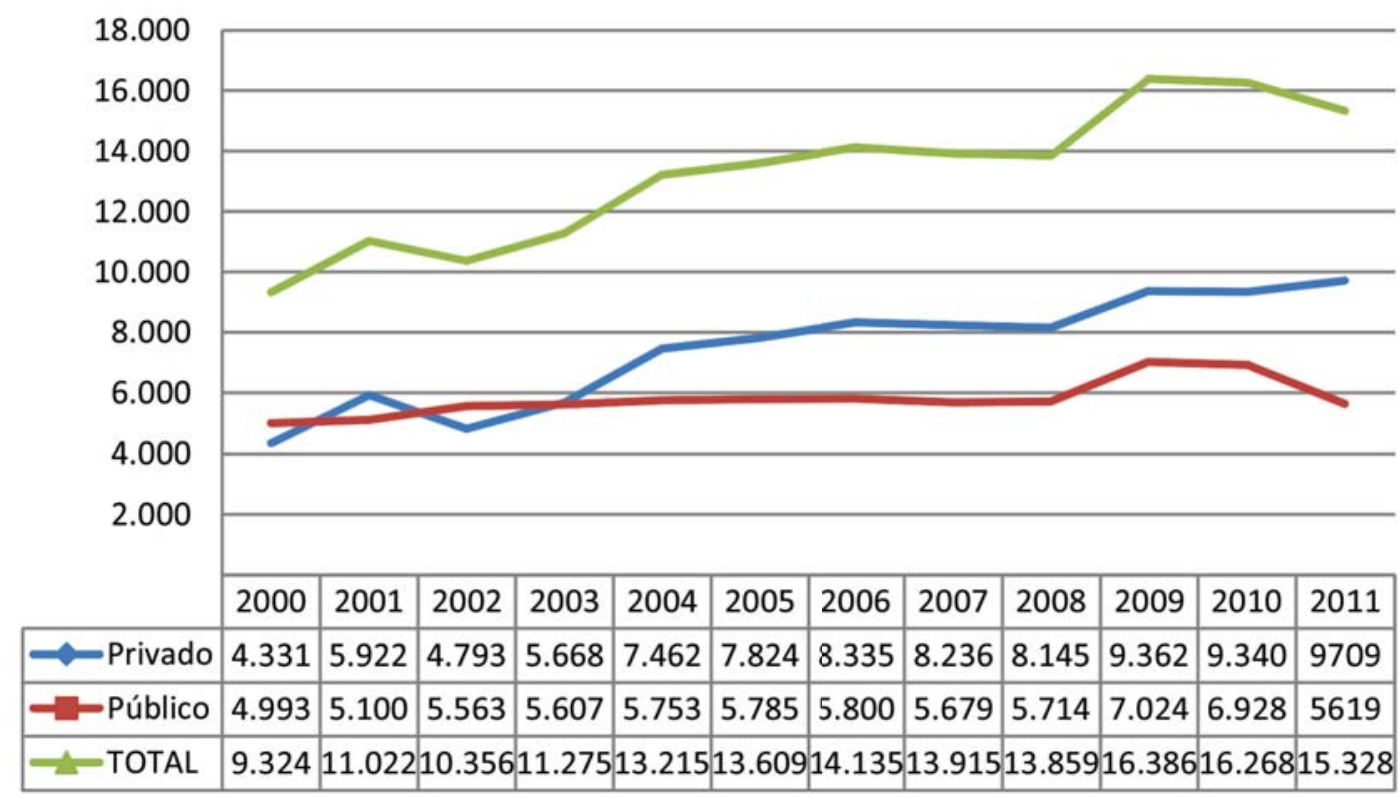

Fonte: INEP/MEC, SIGRAS/Estação de Trabalho IMS/UERJ do ObservaRH, 2013. 
O gráfico 3 apresenta a tendência do número de cursos de graduação em medicina por regiões do Brasil no período compreendido entre os anos de 2000e 2011. Observa-se que a região Sudeste apresenta maior número de cursos seguida das regiões Nordeste, Norte, Sul e por fim com menor número de cursos a região Centro-Oeste. Contudo, o cálculo da taxa de crescimento assinala que as regiões que apresentaram o maior percentual de acréscimo no número de cursos de nível superior em medicina foram a Norte $(n=111 \%)$, Nordeste $(n=216 \%)$, Centro-Oeste $(n=71 \%)$, Sudeste $(n=62 \%)$ e Sul $(n=47 \%)$, respectivamente, representando um decréscimo de $19 \%$.

Gráfico 03. Cursos de Graduação em Medicina segundo Grandes Regiões. Brasil 2000-2011

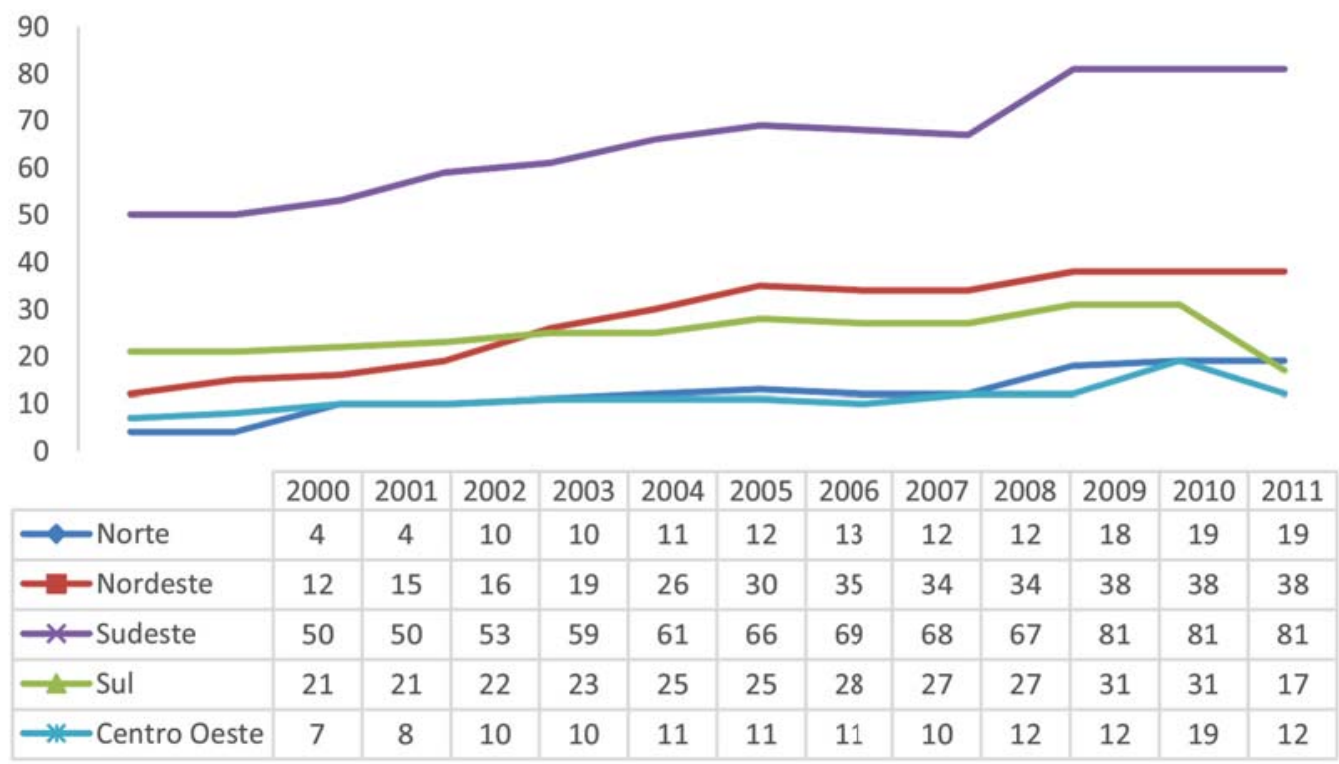

Fonte: INEP/MEC, SIGRAS/Estação de Trabalho IMS/UERJ do ObservaRH, 2012. 
O gráfico 4 apresenta a evolução do número de vagas dos cursos de graduação em medicina no Brasil segundo natureza jurídica no período de 2000-2011. Percebe-se que nos anos iniciais as vagas públicas eram em maior número, no entanto a partir do ano 2000 a esfera privada passou a oferecer maior número de vagas em cursos de graduação em medicina. E com o passar dos anos o número de vagas privadas mais que dobrou o que representa um crescimento de mais de $124 \%$, enquanto na natureza pública esse percentual não alcançou os 13\%.

Gráfico 04. Vagas de Graduação em Medicina por Grandes Regiões e Unidades da Federação segundo Natureza Jurídica. Brasil 1999-2011

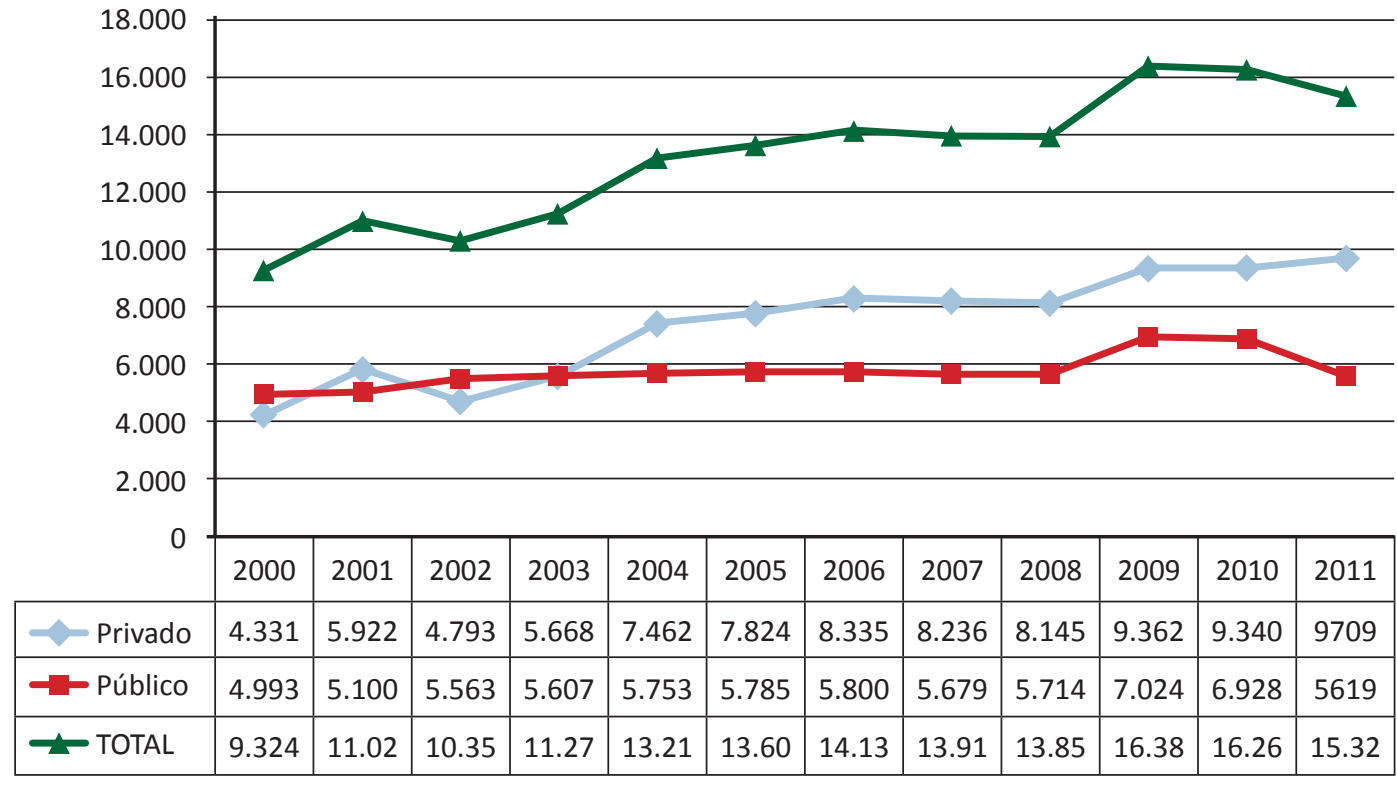

Fonte: INEP/MEC, SIGRAS/Estação de Trabalho IMS/UERJ do ObservaRH, 2012. 
O gráfico 5 traz a evolução do número de vagas dos cursos de graduação em medicina segundo as regiões do Brasil. Nele é possível visualizar que a região Sudeste, durante o período compreendido entre 2000 e 2011, apresentou maior número de vagas em comparação com as demais regiões. Porém, de acordo com os cálculos das taxas de crescimento, ela não foi a região que mais cresceu em número de vagas. O cálculo indicou que a região que mais cresceu foi a Norte $(n=337 \%)$, seguida das regiões Centro-Oeste $(n=108 \%)$, Nordeste $(n=157 \%)$, Sul $(n=-20 \%)$ e Sudeste $(n=48 \%)$. Ainda que a região Sudeste tenha mostrado menor crescimento ela concentra mais de $54 \%$ do total de vagas em medicina.

Gráfico 05. Vagas de Graduação em Medicina segundo Grandes Regiões. Brasil 2000-2011

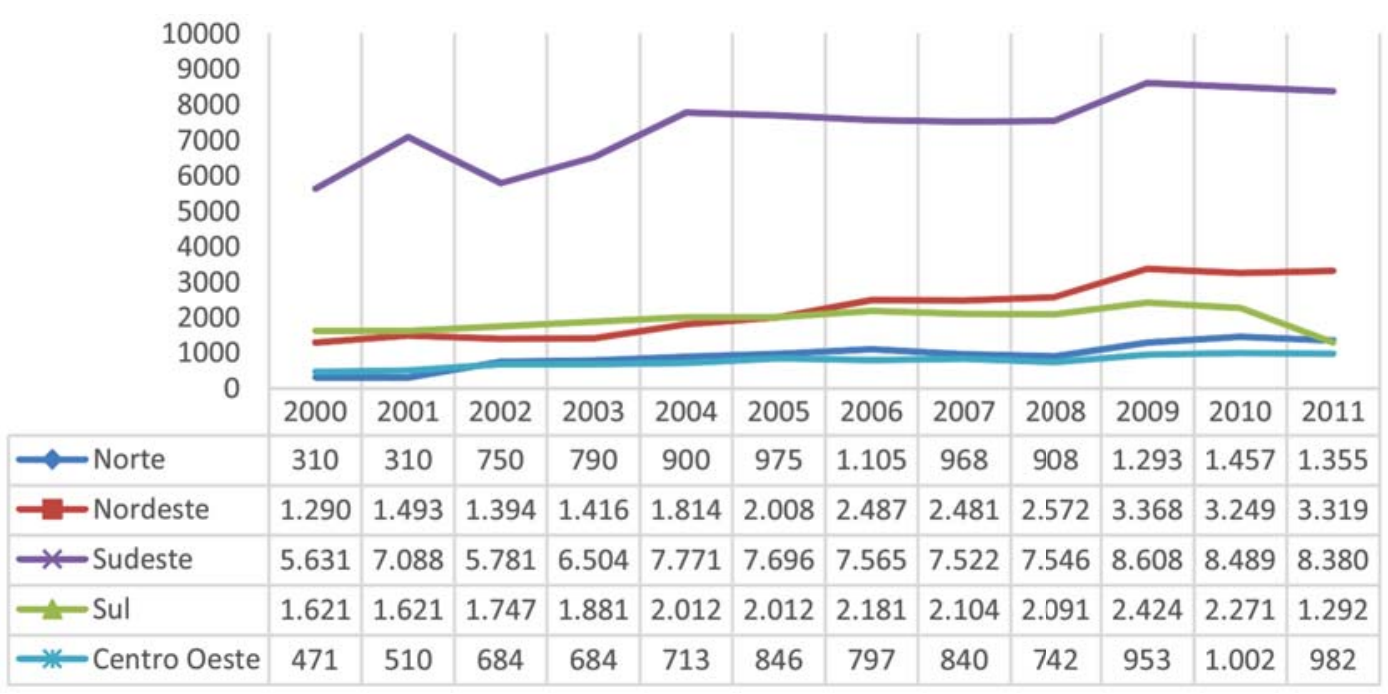

Fonte: INEP/MEC, SIGRAS/Estação de Trabalho IMS/UERJ da Rede ObservaRH, 2012. 
O gráfico 6 mostra a ascensão do número de concluintes de cursos de graduação em medicina segundo a natureza jurídica no período de 2000-2011. Visualiza-se que no ano de 2000 a diferença de concluintes entre as esferas era de quase o dobro com maior número na esfera pública, com o passar dos anos essa diferença foi diminuindo até que em 2011 o número de egressos foi maior na esfera privada. Consequentemente, a taxa de crescimento do número de egressos na esfera privada foi de 198\% enquanto na pública foi de apenas 9\%.

Gráfico 06. Concluintes dos cursos de graduação em medicina segundo natureza jurídica, Brasil, 2000-2011

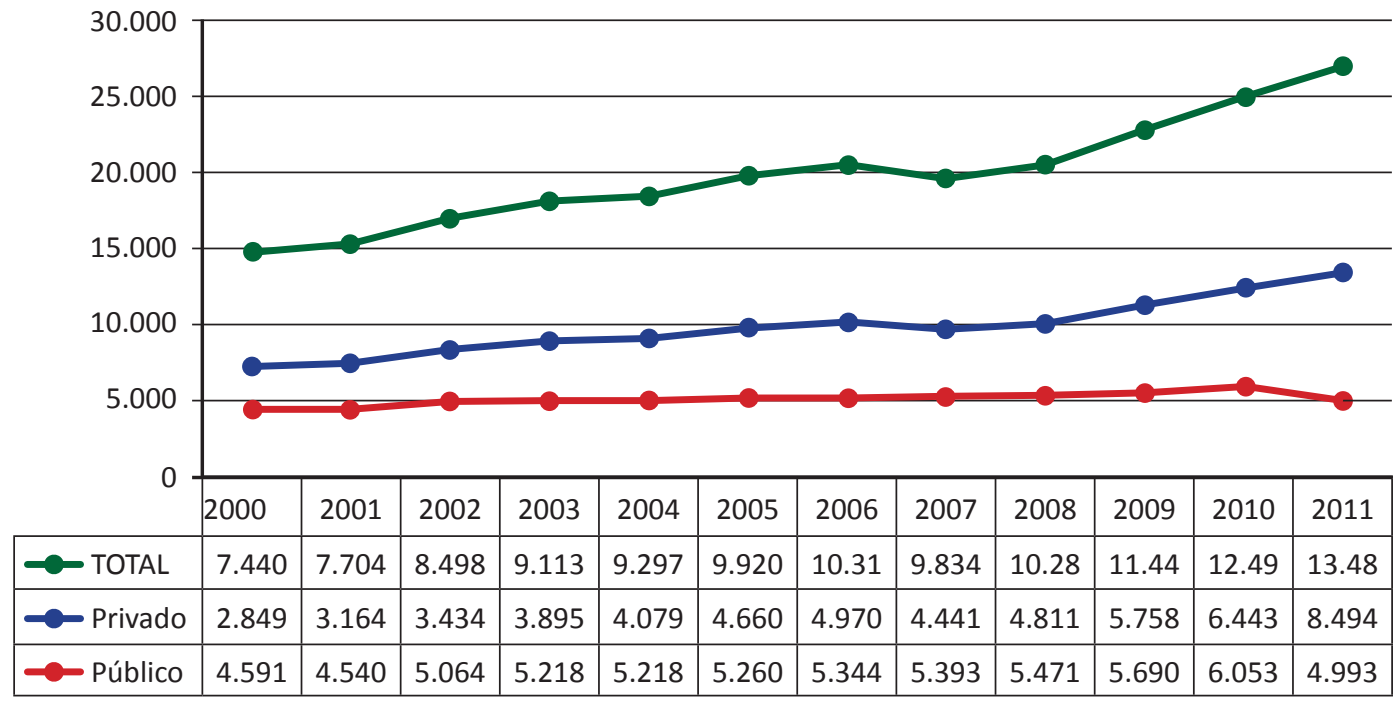

Fonte: INEP/MEC, SIGRAS/Estação de Trabalho IMS/UERJ da Rede ObservaRH, 2012. 
O gráfico 7 apresenta a evolução do número de concluintes dos cursos de graduação em medicina segundo as regiões do Brasil no período de 2000-2011. O número de concluintes no ano de 2000 era maior nas regiões Sudeste e Nordeste e menor nas regiões Norte e Centro-Oeste. O ano de 2011 mostrou algumas alterações, a região Sul ultrapassou a Nordeste em número de egressos a partir do ano de 2005, quando esta apresentou uma diminuição de concluintes em relação ao ano de 2004, e embora tenha aumentado com o passar dos anos a região Sul apresentou taxa de crescimento superior. O cálculo das taxas de crescimento de cada região aponta que a região Centro-Oeste seguida da Norte apresentam os maiores percentuais de elevação quais sejam 228\% e 207\%. As regiões Sul, Nordeste e Sudeste cresceram 71\%, 29\% e 1\%, respectivamente. E embora, o crescimento da região Sudeste tenha sido o menor em relação às demais regiões, ela ainda apresenta o maior número de concluintes.

Gráfico 07. Concluintes dos Cursos de Graduação em Medicina segundo Grandes Regiões. Brasil, 2000-2011

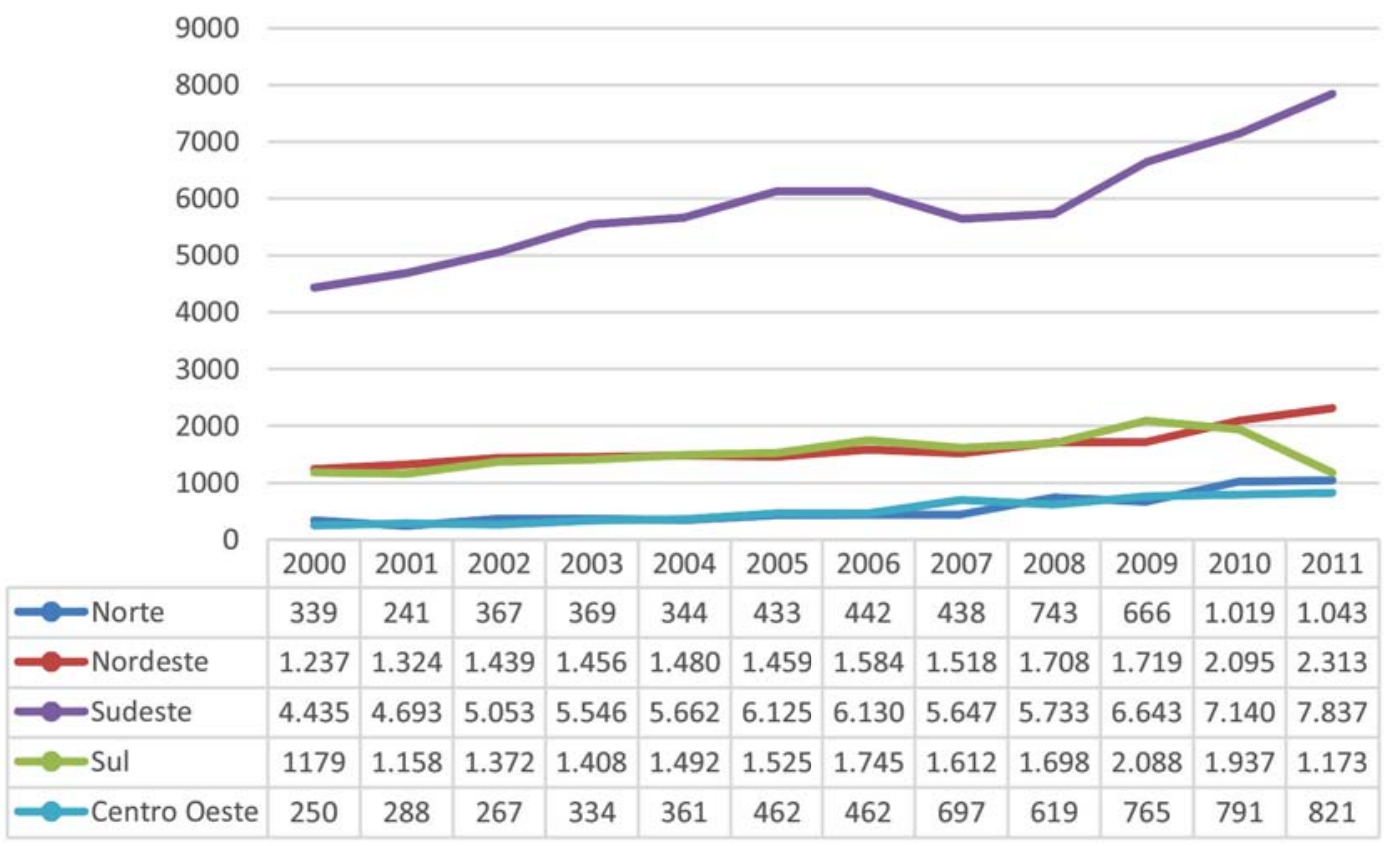

Fonte: INEP/MEC, SIGRAS/Estação de Trabalho IMS/UERJ da Rede ObservaRH, 2012. 
O gráfico 8 aborda sobre o número de vagas e de egressos dos cursos de graduação em medicina no período de 2000-2011. A visualização permite verificar que o número de vagas sempre foi superior ao de egressos. A taxa de crescimento do número de vagas no período foi de 64\%, enquanto a de egressos foi de 81\%.Dessa forma, pode-se afirmar que o número de vagas para cursar nível superior em medicina tem mostrado uma tendência de contínuo crescimento, e apesar de a curva do número de concluintes também ter apresentado ascendência, o crescimento não foi proporcional, de modo que é possível afirmar que as vagas não são preenchidas por completo e/ou há um alto percentual de desistência durante o curso.

Gráfico 8. Vagas e Concluintes dos Cursos de Graduação em Medicina por Brasil segundo Natureza Jurídica. Brasil, 2000-2011

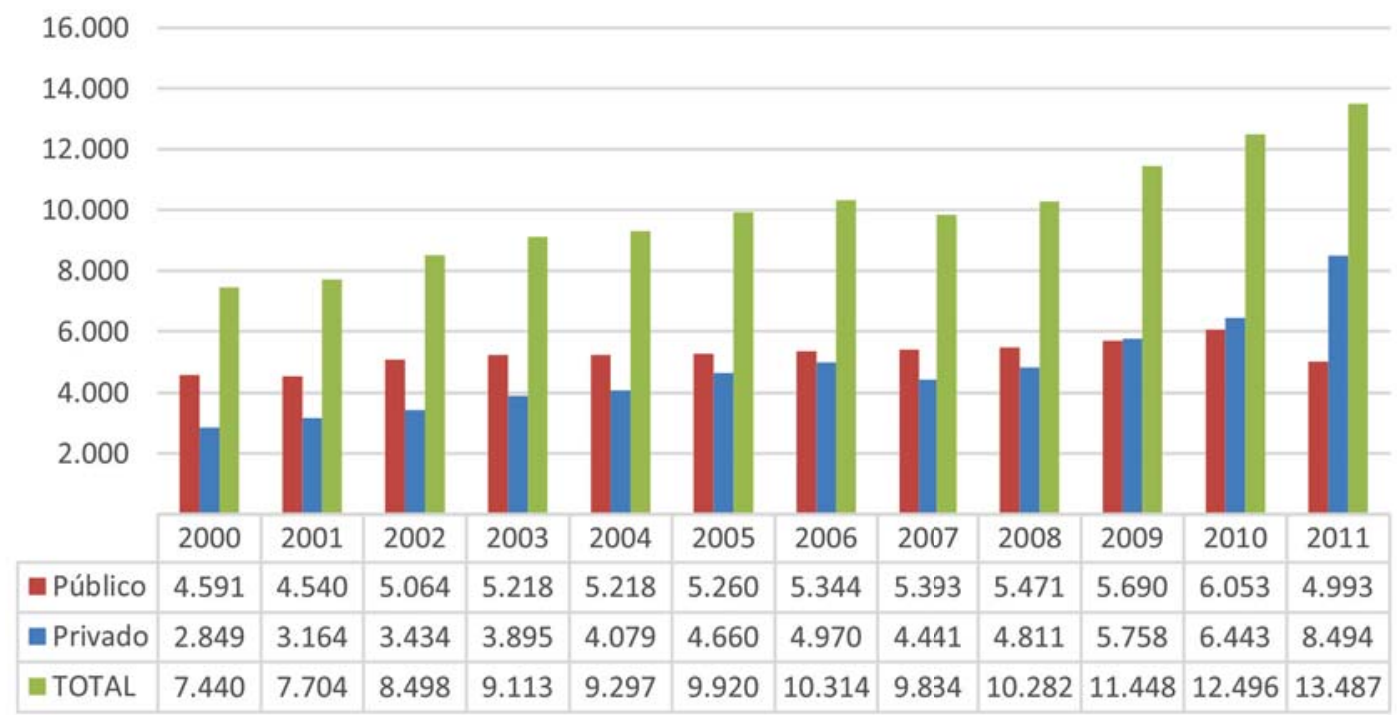

Fonte: INEP/MEC, SIGRAS/Estação de Trabalho IMS/UERJ da Rede ObservaRH, 2012. 


\subsection{2 | Enfermagem}

O gráfico 9 traz a curva de evolução do número de cursos de graduação em enfermagem no Brasil segundo a natureza jurídica no período de 2000-2011. É possível visualizar um crescimento das variáveis apresentadas, sobretudo a partir de 2005. Embora o aumento do número de cursos também tenha ocorrido na esfera pública $(\mathrm{n}=124 \%)$, o de natureza privada cresceu seis vezes mais no mesmo período ( $\mathrm{n}=642 \%)$.

Gráfico 09. Cursos de Graduação em Enfermagem segundo natureza jurídica, Brasil, 2000-2011

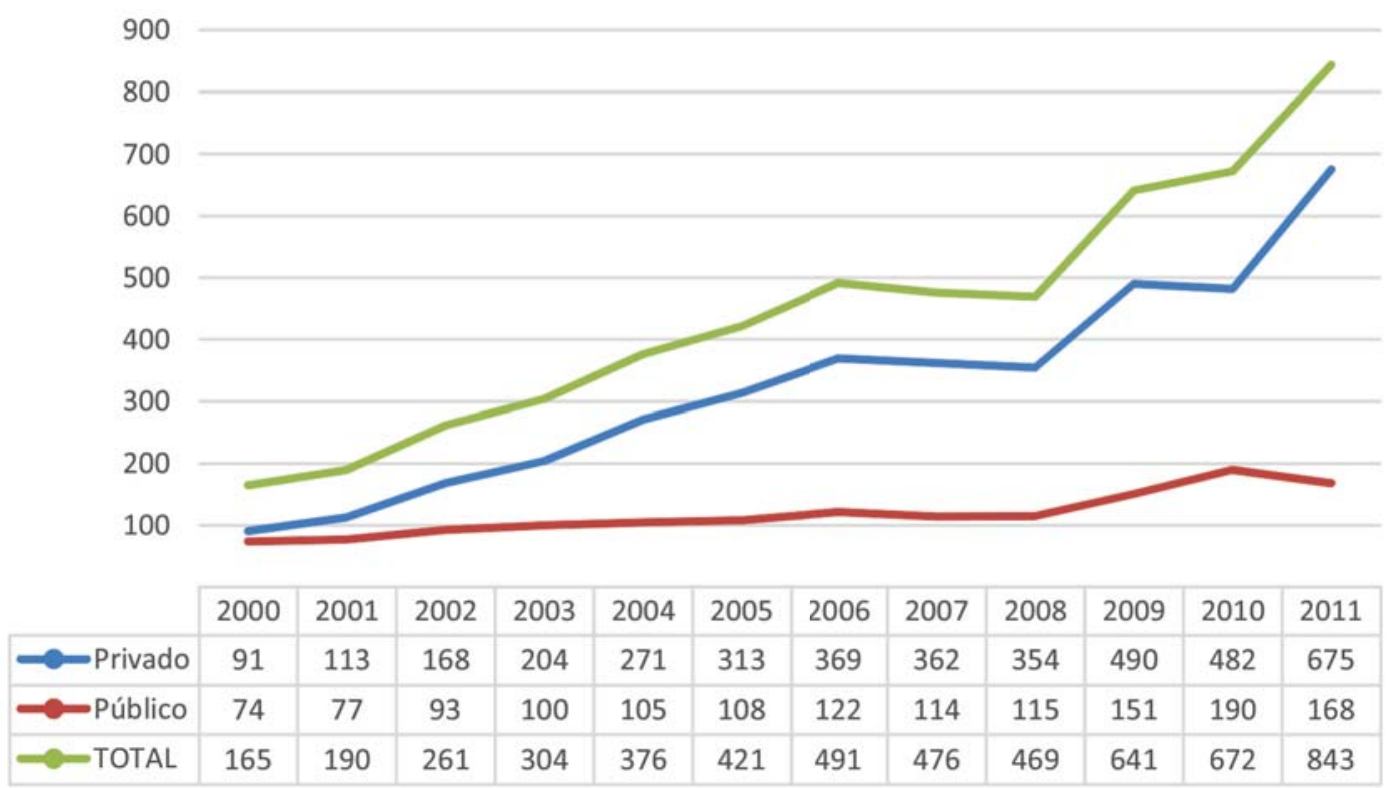

Fonte: INEP/MEC, SIGRAS/Estação de Trabalho IMS/UERJ da Rede ObservaRH, 2012. 
O gráfico 10 mostra a tendência do número de cursos de graduação em enfermagem por regiões do Brasil no período compreendido entre os anos de 2000 e 2011. Observa-se que a região Sudeste apresenta maior número de cursos seguida das regiões Nordeste, Sul, Centro-Oeste e por fim com menor número de cursos a região Norte. Não obstante ao disposto nas curvas, o cálculo da taxa de crescimento aponta que as regiões Centro- Oeste $(\mathrm{n}=445 \%)$ e Nordeste $(461 \%)$ apresentaram o maior percentual de ascensão no número de cursos de nível superior em enfermagem, seguido das regiões Sudeste ( $\mathrm{n}=327 \%)$, Norte $(290 \%)$ e Sul $(108 \%)$.

Gráfico 10. Cursos de Graduação em Enfermagem segundo Grandes Regiões. Brasil, 2000-2011

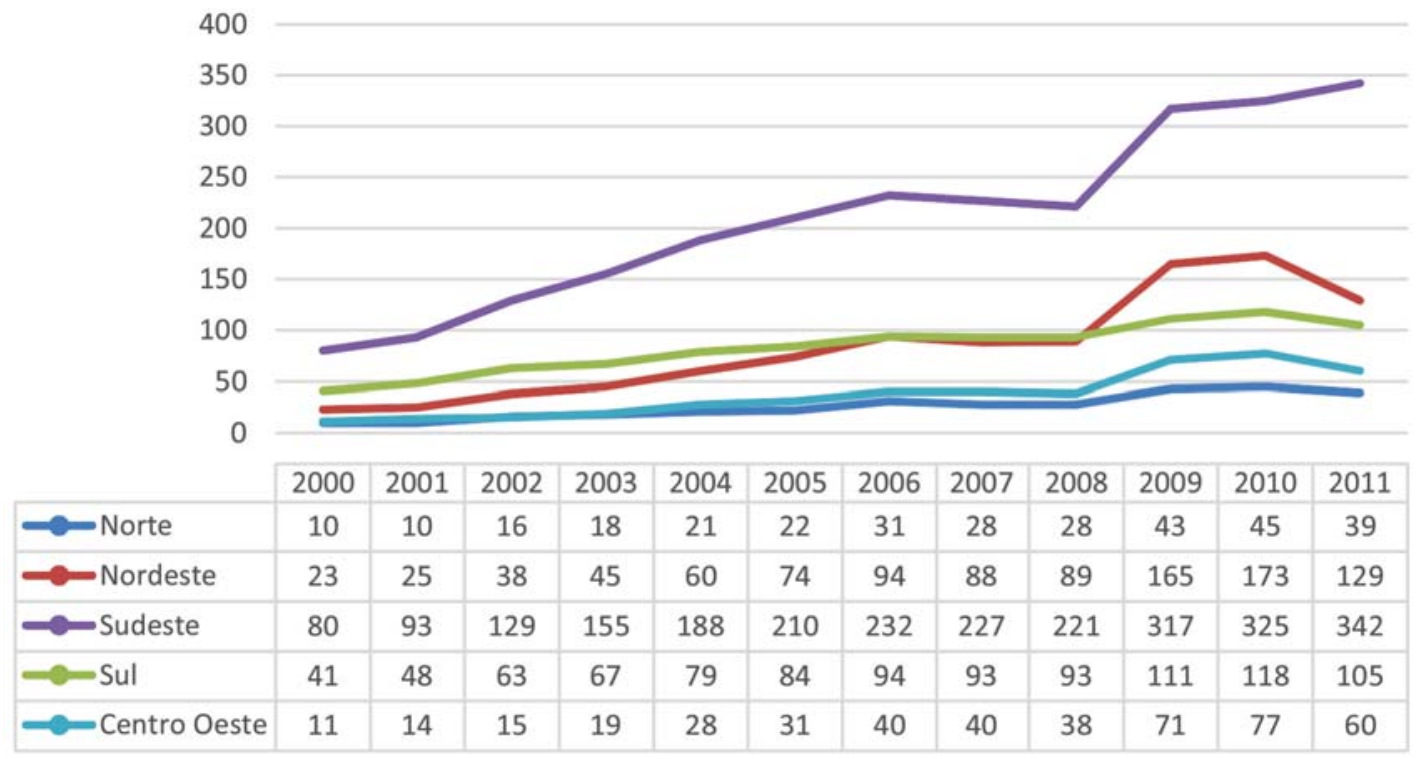

Fonte: INEP/MEC, SIGRAS/Estação de Trabalho IMS/UERJ da Rede ObservaRH, 2012 
O gráfico 11 apresenta a evolução do número de vagas dos cursos de graduação em enfermagem segundo natureza jurídica no período de 2000-2011. A curva que representa o crescimento de vagas no setor privado é nitidamente mais ascendente que a do setor público, de modo que a taxa de crescimento no primeiro foi superior a 680\% e no segundo pouco mais de 127\%. Portanto os dados de 2011 apontam que o número de vagas em estabelecimentos privados ultrapassa em mais de cinco vezes as do setor público.

Gráfico 11. Vagas dos Cursos de Graduação em Enfermagem segundo Natureza Jurídica. Brasil, 2000-2011

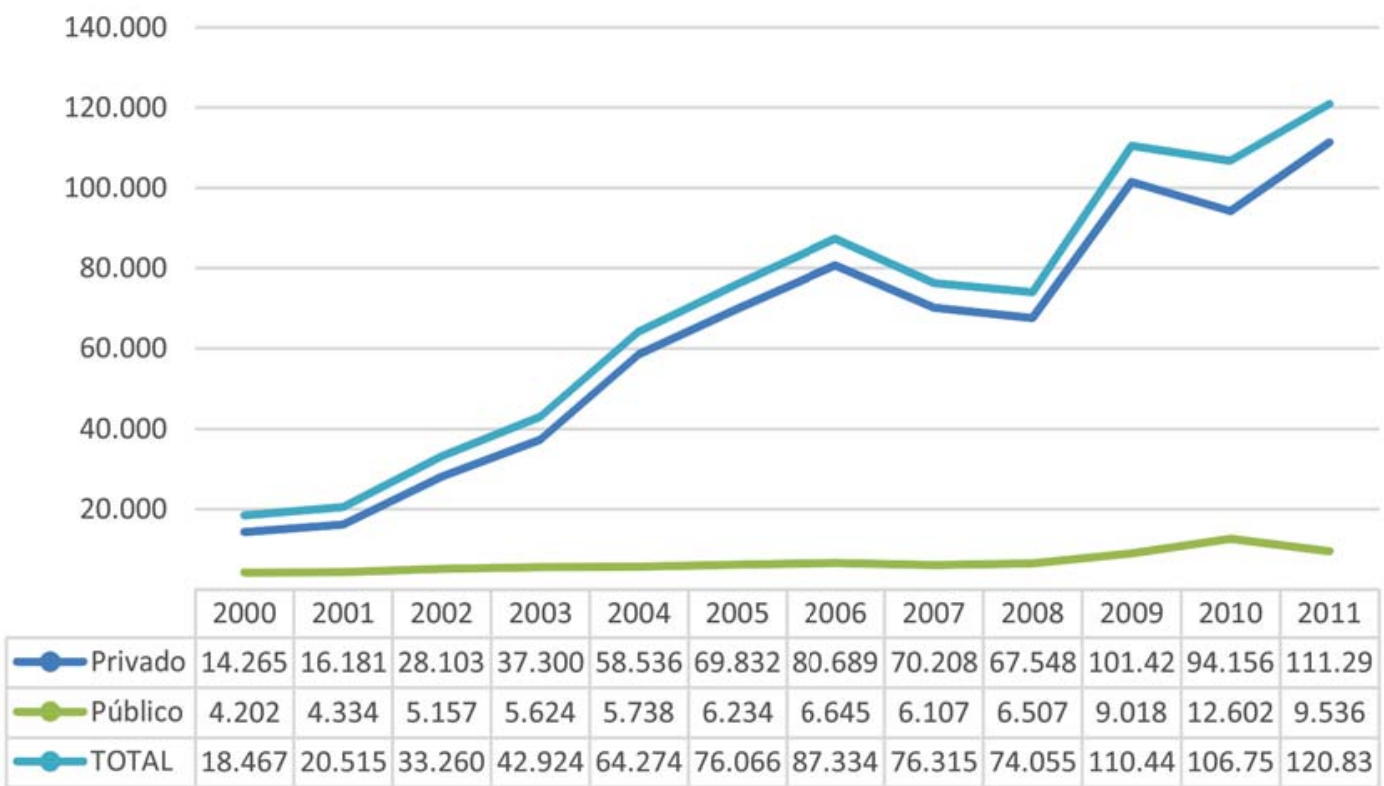

Fonte: INEP/MEC, SIGRAS/Estação de Trabalho IMS/UERJ da Rede ObservaRH, 2012. 
O gráfico 12 traz a evolução do número de vagas dos cursos de graduação em enfermagem segundo as regiões do Brasil. Nele é possível visualizar que a região Sudeste se destaca, pois já em 2000 apresentava número de vagas superior às demais regiões, e ao longo dos anos essa tendência não se modificou. Entretanto, no que se refere a taxa de crescimento, o cálculo indica que a região que mais cresceu foi a centro oeste $(n=1047 \%)$ seguida das regiões Norte $(n=1142 \%)$ e Nordeste $(n=968 \%)$. A região Sudeste cresceu $458 \%$ e a Sul 182\%. De toda forma, os estados de São Paulo, Minas Gerais, Espírito Santo e Rio de Janeiro detém mais de 54\% do total de vagas dos cursos de graduação em enfermagem.

Gráfico 12. Vagas dos cursos de graduação em Enfermagem segundo grandes regiões. Brasil, 20002011

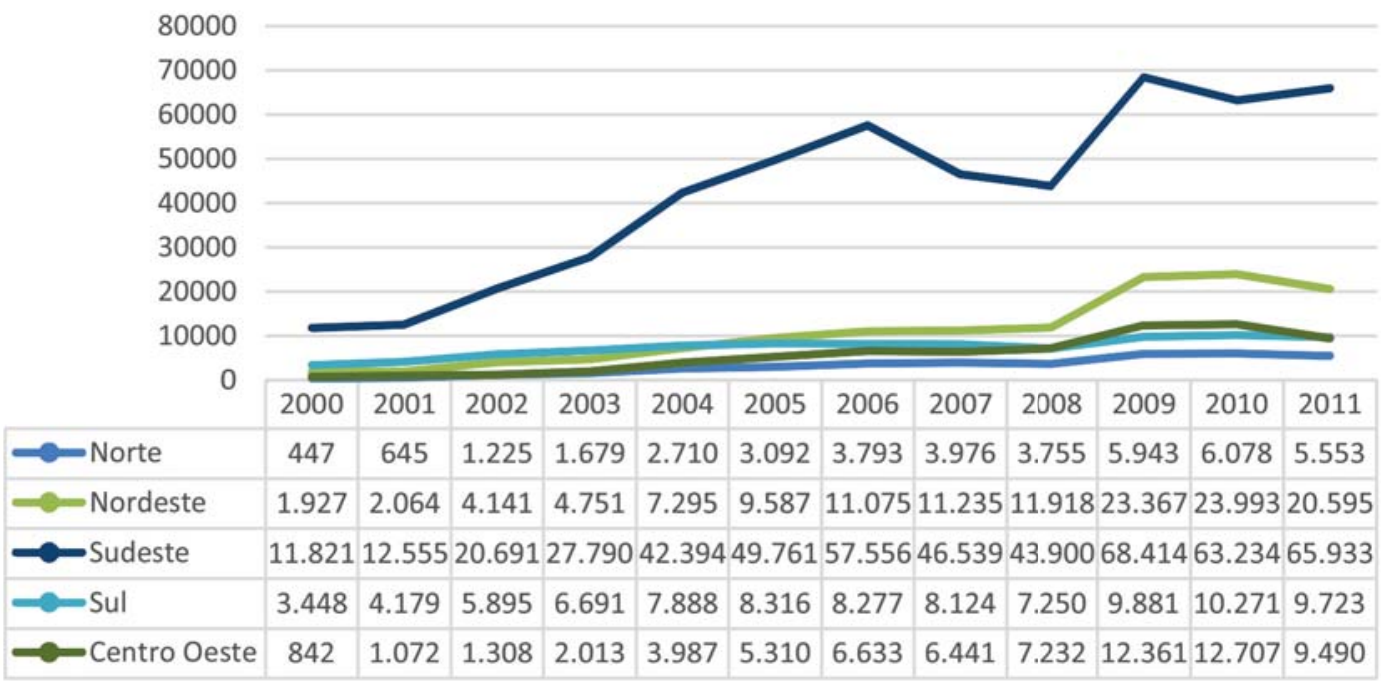

Fonte: INEP/MEC, SIGRAS/Estação de Trabalho IMS/UERJ da Rede ObservaRH, 2012 
O gráfico 13 informa a progressão do número de concluintes de cursos de graduação em enfermagem segundo a natureza jurídica. No período, nota-se que, se no ano de 1999 a diferença entre as duas esferas era pequena, estando no setor público um maior contingente de egressos, após 10 anos esse cenário se altera completamente, demonstrando uma taxa de crescimento de $1786 \%$ de concluintes em estabelecimentos privados enquanto o segmento público apresentou um aumento de $111 \%$ de egressos.

Gráfico 13. Concluintes dos Cursos de Graduação em Enfermagem segundo Natureza Jurídica. Brasil, 2000-2011

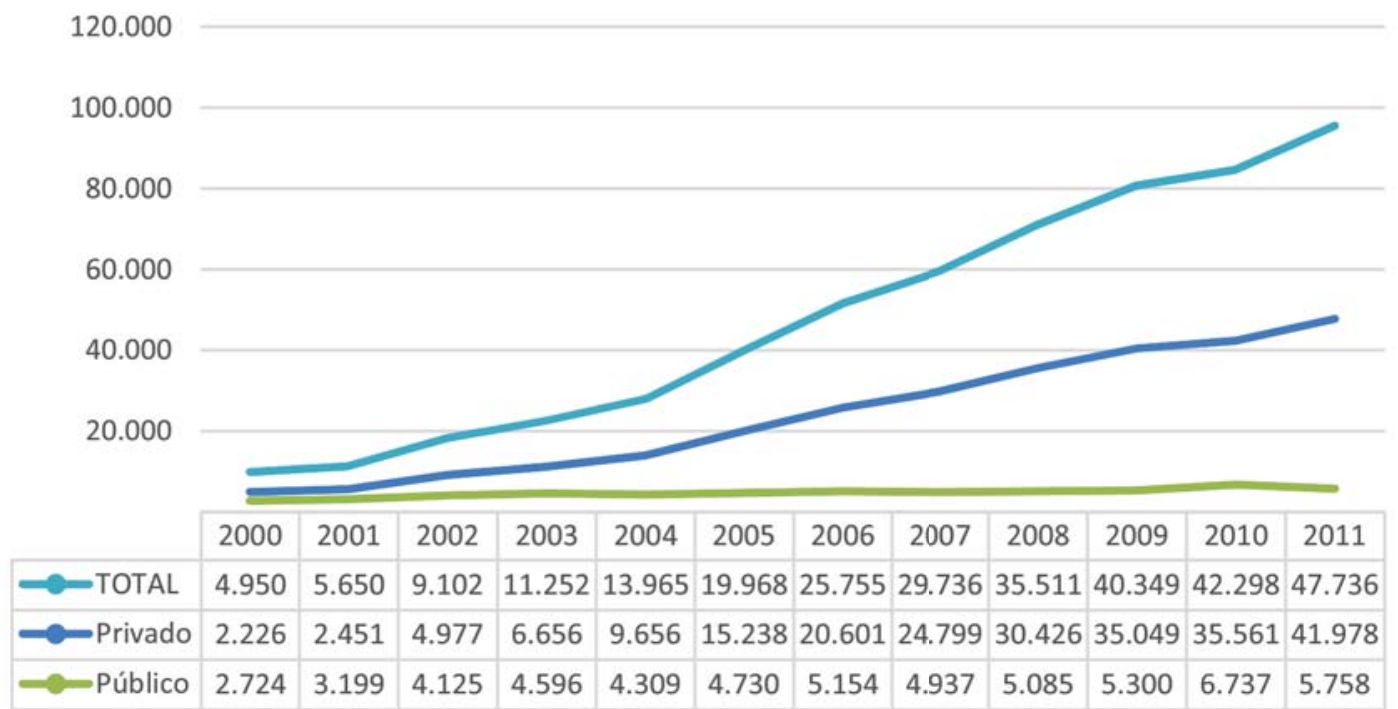

Fonte: INEP/MEC, SIGRAS/Estação de Trabalho IMS/UERJ da Rede ObservaRH, 2011 
O gráfico 14 apresenta a evolução do número de concluintes dos cursos de graduação em enfermagem segundo as regiões do Brasil no período de 2000-2011. O número de concluintes no ano de 2000 era maior nas regiões Sudeste e Nordeste e menor no centro oeste e norte. Dez anos depois esse quadro não se alterou muito, exceto pelo fato de a região Centro-Oeste ter ultrapassado a Norte em número de concluintes. E embora a curva da região Sudeste se destaque, o cálculo das taxas de crescimento de cada região assinala que a região Centro-Oeste seguida da região Nordeste apresenta os maiores percentuais de ascensão, quais sejam 1300\% e 929\%. As regiões Sudeste, Sul e Norte cresceram 742\%, 291\% e 256\%, respectivamente.

Gráfico 14. Concluintes dos Cursos de Graduação em Enfermagem segundo Grandes Regiões. Brasil, 2000-2011.

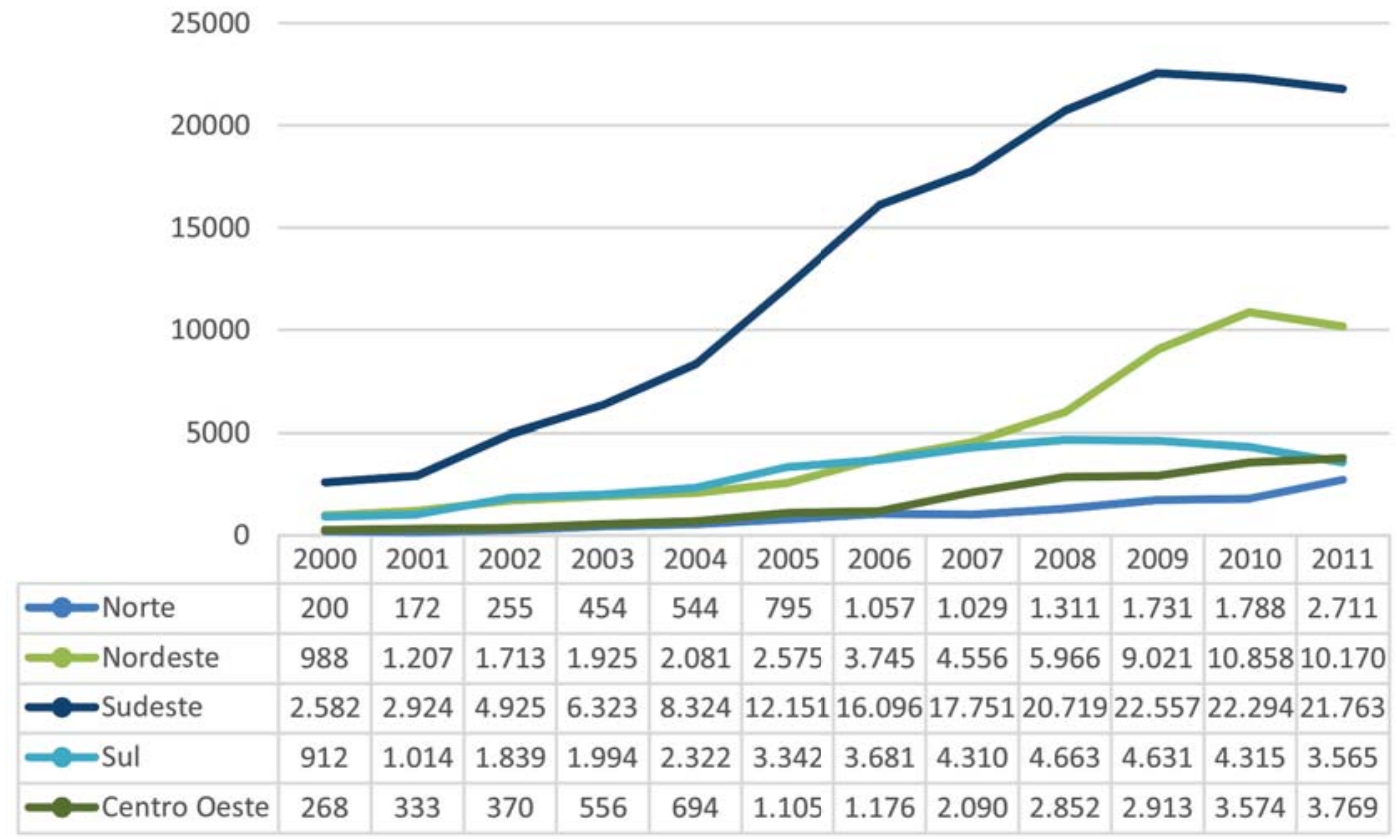

Fonte: INEP/MEC, SIGRAS/Estação de Trabalho IMS/UERJ da Rede ObservaRH, 2012 
O gráfico 15 versa sobre o número de vagas e de egressos dos cursos de graduação em enfermagem no período de 2000-2011. A visualização permite verificar que o número de vagas era e ainda é superior ao de egressos. A taxa de crescimento em dez anos do número de vagas foi de $554 \%$, enquanto a de egressos foi de $864 \%$. Dessa forma, pode-se afirmar que no Brasil abrem-se cada vez mais vagas para cursar graduação em enfermagem, e como o número de concluintes não acompanhou o de vagas, pode-se supor que as vagas não são preenchidas por completo e/ou há um alto percentual de desistência durante o curso.

Gráfico 15. Vagas e Egressos do Curso de Graduação em Enfermagem. Brasil, 2000-2011

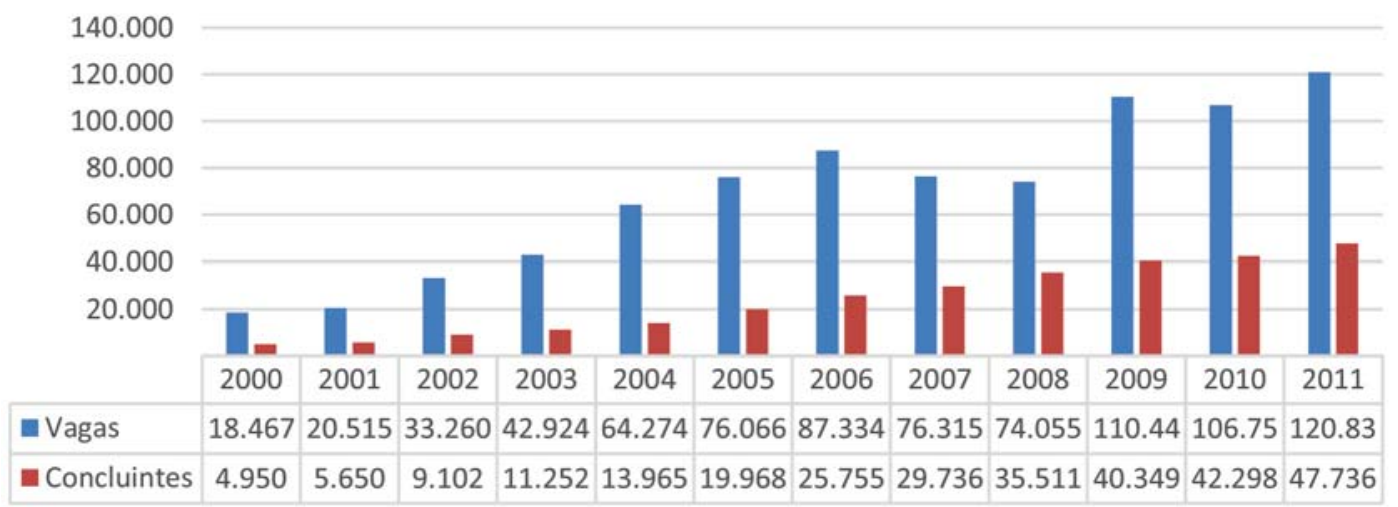

Fonte: INEP/MEC, SIGRAS/Estação de Trabalho IMS/UERJ da Rede ObservaRH, 2011 


\subsection{3 | Odontologia}

O gráfico 16 traz a curva de evolução do número de cursos de graduação em odontologia no Brasil segundo a natureza jurídica no período de 2000-2011. Visualiza-se o crescimento das curvas, sobretudo da que representa a esfera privada, que apresentou taxa de crescimento de $96 \%$, enquanto o crescimento da pública foi de apenas $13 \%$.

Gráfico 16. Cursos de graduação em Odontologia segundo natureza jurídica. Brasil, 2000-2011

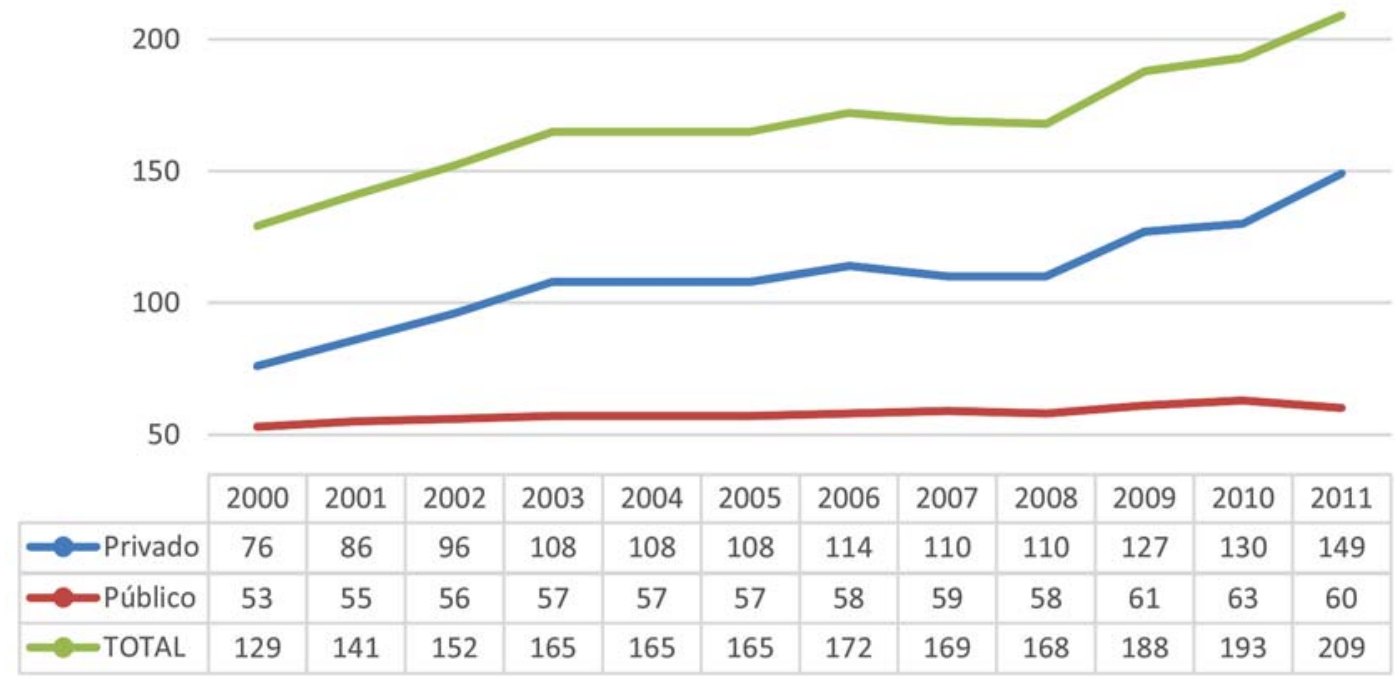

Fonte: INEP/MEC, SIGRAS/Estação de Trabalho IMS/UERJ da Rede ObservaRH, 2012. 
O gráfico 17 indica a tendência do número de cursos de graduação em odontologia por regiões do Brasil no período compreendido entre os anos de 2000 e 2011. Observa-se que a região Sudeste apresenta maior número de cursos seguida das regiões Nordeste e Sul que oferecem o mesmo número de cursos, Norte e por fim com menor número de cursos a região Centro-Oeste. Não obstante ao demonstrado nas curvas, o cálculo da taxa de crescimento aponta que as regiões Norte $(\mathrm{n}=300 \%)$ e Nordeste (141\%) apresentaram o maior percentual de ascensão no número de cursos de nível superior em odontologia, seguidas das regiões Centro-Oeste $(n=33 \%)$, Sul $(39 \%)$ e Sudeste $(\mathrm{n}=38 \%)$.

Gráfico 17. Cursos de graduação em Odontologia segundo grandes Regiões. Brasil, 2000-2011

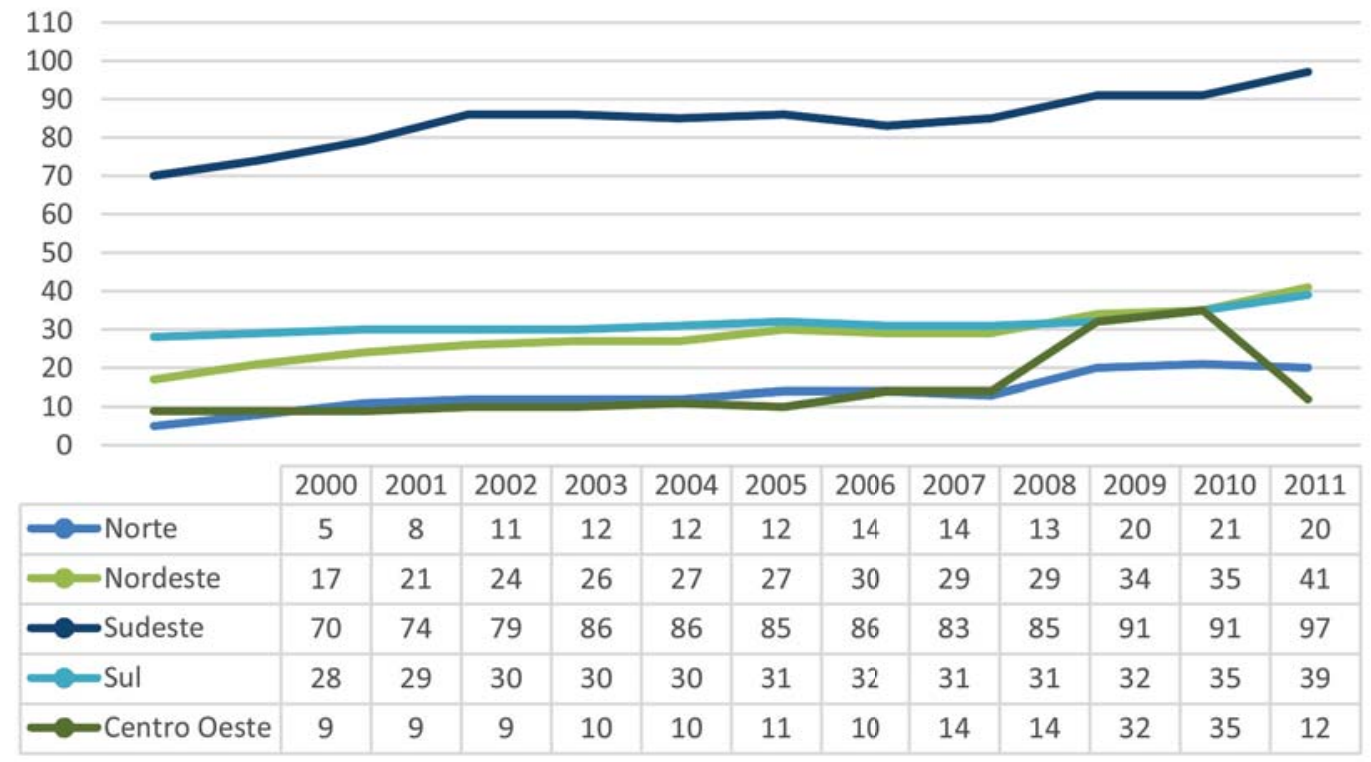

Fonte: INEP/MEC, SIGRAS/Estação de Trabalho IMS/UERJ da Rede ObservaRH, 2012. 
O gráfico 18 apresenta a evolução do número de vagas dos cursos de graduação em odontologia no Brasil segundo natureza jurídica no período de 2000 - 2011. A curva que representa o crescimento de vagas no setor privado se destaca, visto que a taxa de crescimento foi superior a $85 \%$ enquanto no setor público houve um decréscimo de 11\%. Em consequência os dados de 2011 apontam que o número de vagas em unidades privadas ultrapassa em mais de três vezes o número de vagas no setor público.

Gráfico 18. Vagas dos cursos de graduação em Odontologia segundo natureza jurídica. Brasil, 20002011

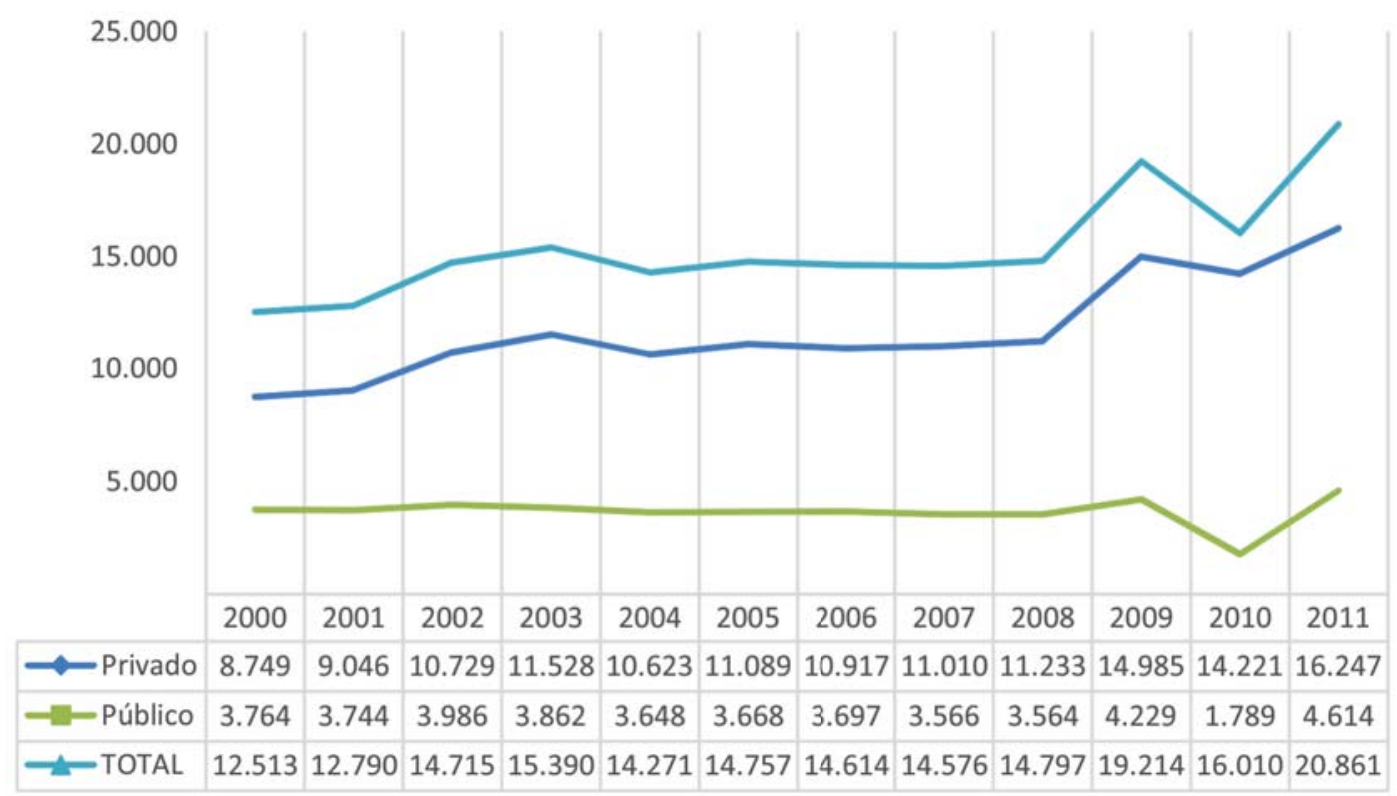

Fonte: INEP/MEC, SIGRAS/Estação de Trabalho IMS/UERJ da Rede ObservaRH, 2012. 
O gráfico 19 traz a evolução do número de vagas dos cursos de graduação em odontologia segundo as regiões do Brasil. Nota-se que a região Sudeste ao longo dos dez anos superou as outras regiões em número de vagas. Entretanto, ela não foi a região que apresentou a maior taxa de crescimento. O cálculo indica que a região que mais aumentou o número de vagas foi a região Norte $(n=505 \%)$, seguida das regiões Nordeste (183\%), Centro-Oeste (67\%), Sul (41\%)e por fim Sudeste (33\%). Não obstante a menor taxa de crescimento ter sido da região Sudeste, ela detém mais de $62 \%$ do total de vagas dos cursos de graduação em odontologia do Brasil.

Gráfico 19. Vagas dos cursos de graduação em Odontologia segundo Grandes Regiões. Brasil, 2000-2011

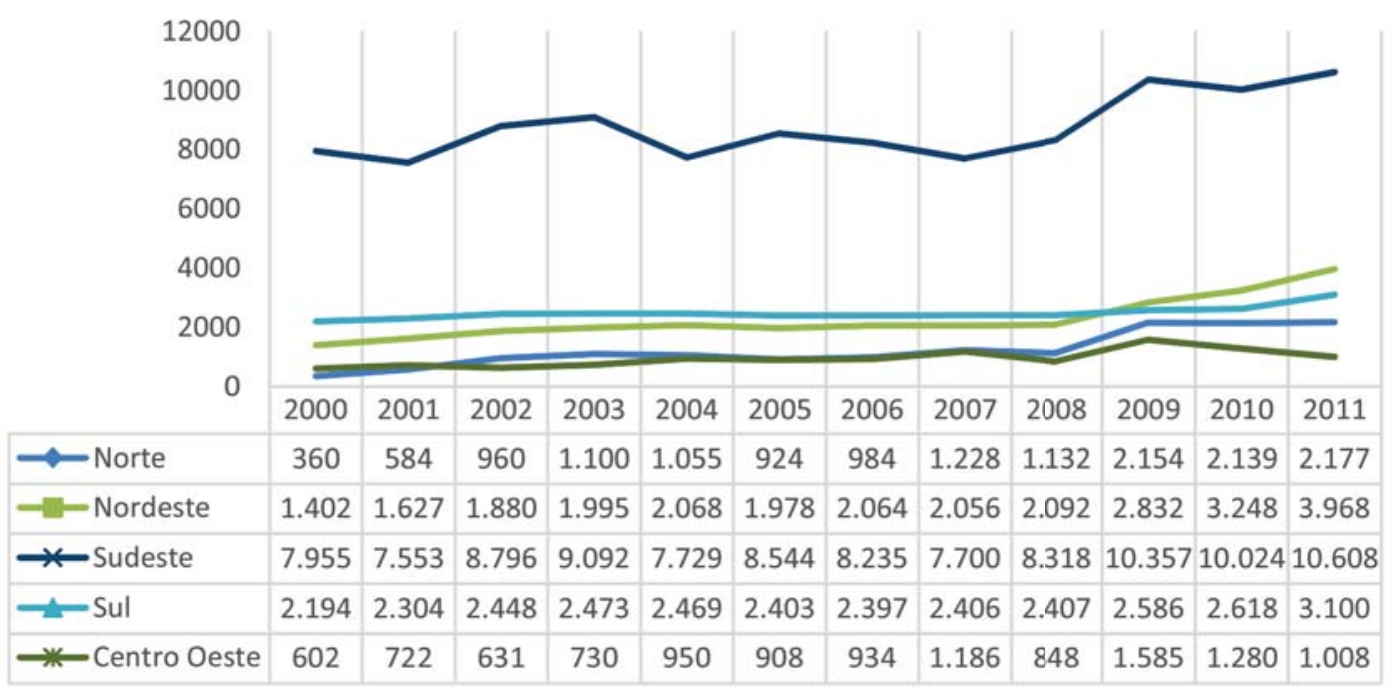

Fonte: INEP/MEC, SIGRAS/Estação de Trabalho IMS/UERJ da Rede ObservaRH, 2012. 
O gráfico 20 informa a progressão do número de concluintes de cursos de graduação em odontologia segundo a natureza jurídica no período de 2000-2011. Notase que, embora a diferença de concluintes fosse pequena entre as duas esferas, desde o ano de 2000, o número de egressos já era maior na esfera privada. Essa diferença continuou aumentando com o passar dos anos de modo que a taxa de crescimento no número de concluintes na esfera privada foi superior a 38\%. A esfera pública por sua vez, ao longo dos dez anos apresentou períodos de aumento e queda no número de concluintes, resultando numa taxa de crescimento de apenas 5\%.

Gráfico 20. Concluintes dos cursos de Graduação em Odontologia segundo natureza jurídica. Brasil, 2000-2011

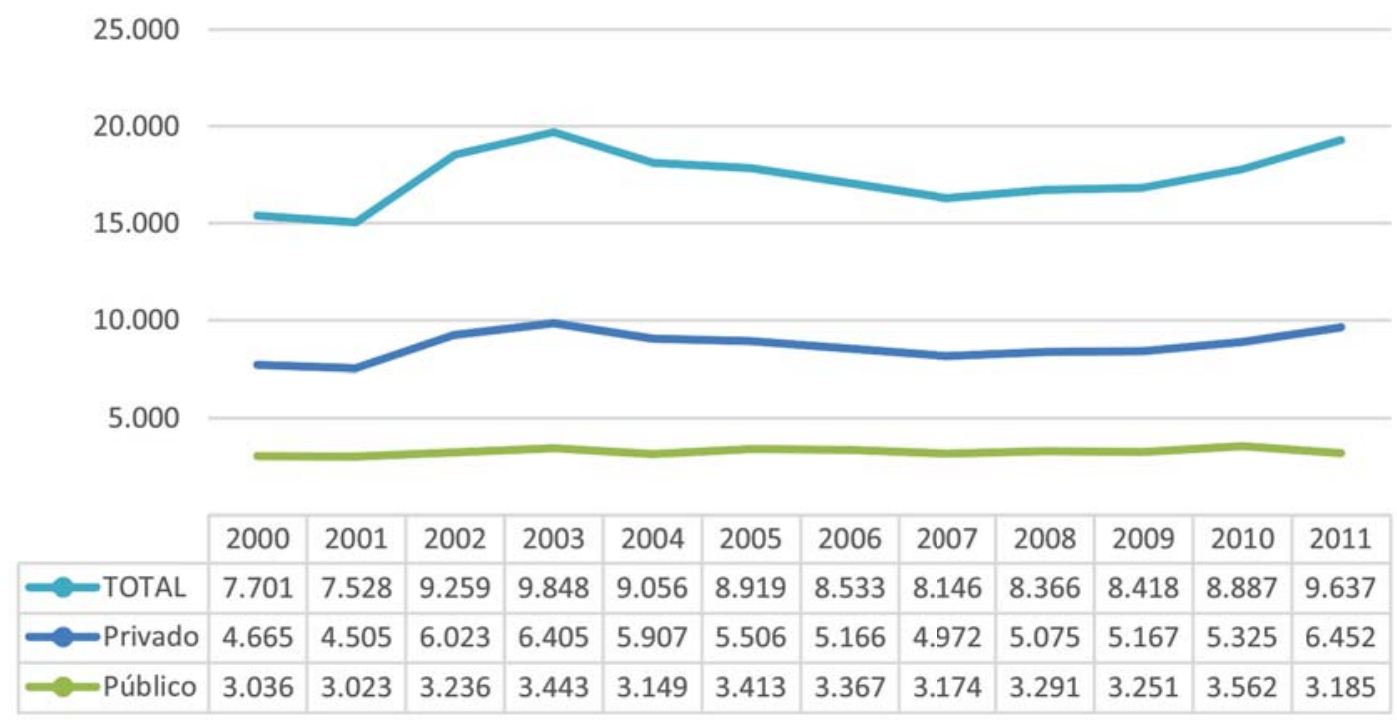

Fonte: INEP/MEC, SIGRAS/Estação de Trabalho IMS/UERJ da Rede ObservaRH, 2012. 
O gráfico 21 apresenta a evolução do número de concluintes dos cursos de graduação em odontologia segundo as regiões do Brasil no período de 2000-2011. O número de concluintes no ano de 2000 era maior nas regiões Sudeste e sul e menor na região Norte. Dez anos depois esse quadro não se alterou muito, exceto pelo fato de a região Sudeste ter reduzido o número de egressos. As taxas de crescimento das regiões Norte e Centro-Oeste apresentam os maiores percentuais de ascensão quais sejam de $670 \%$ e de $105 \%$ respectivamente, enquanto a região Sudeste apresentou decréscimo de $10 \%$.

Gráfico 21. Concluintes dos cursos de graduação de Odontologia segundo grandes Regiões. Brasil, 2000-2011

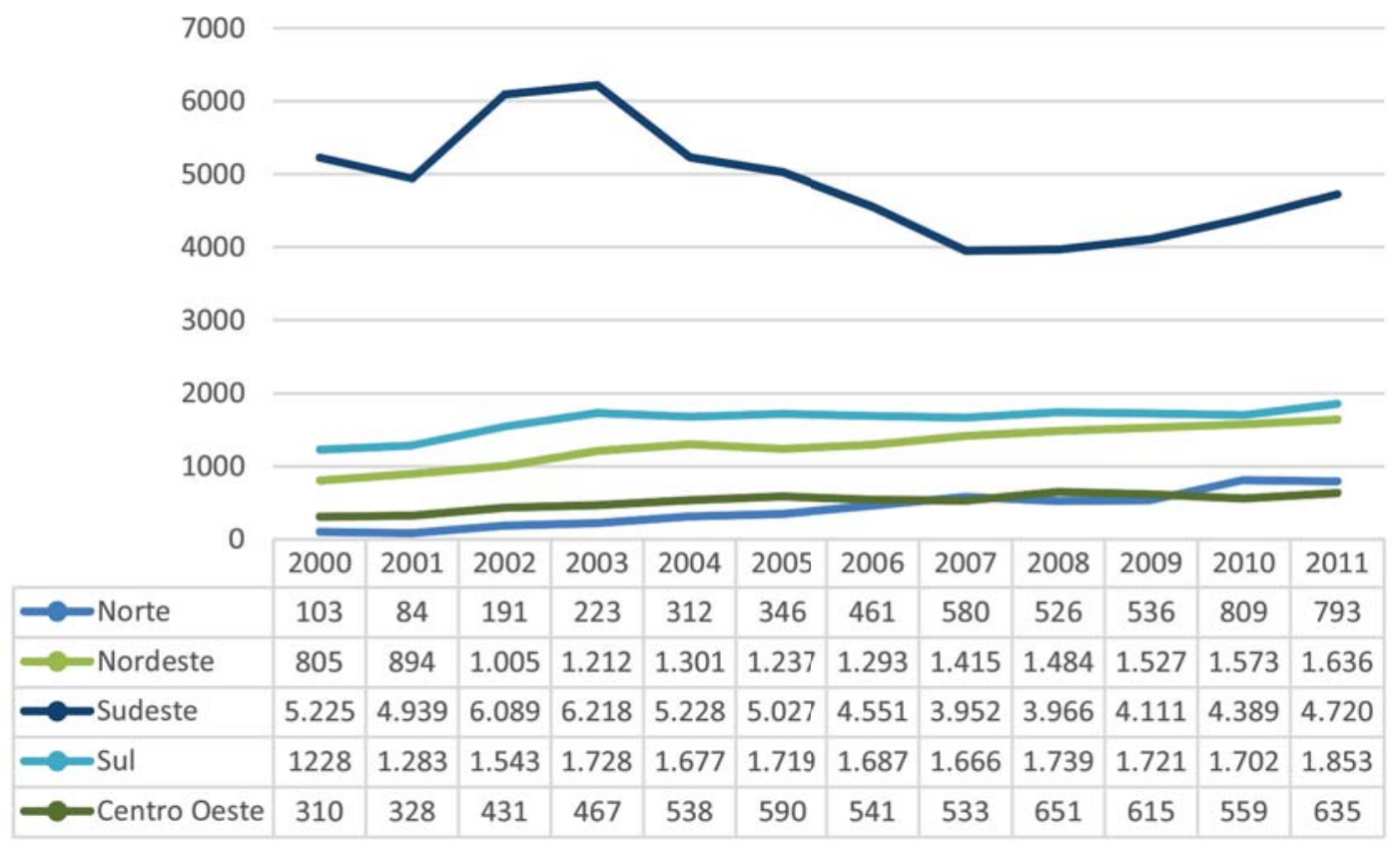

Fonte: INEP/MEC, SIGRAS/Estação de Trabalho IMS/UERJ da Rede ObservaRH, 2012. 
O gráfico 22 apresenta o número de vagas e de concluintes dos cursos de graduação em odontologia no período de 2000 - 2011. Verifica-se que o número de vagas era e ainda é superior ao de egressos. A taxa de crescimento em dez anos do número de vagas foi de $63 \%$,enquanto a de egressos foi de $25 \%$.Pode-se afirmar que no Brasil abrem-se cada vez mais vagas para cursar graduação em odontologia, e como o número de concluintes não acompanhou o de vagas, pode-se supor que as vagas não são preenchidas por completo e/ou há um alto percentual de desistência durante o curso.

Gráfico 22. Vagas e concluintes dos cursos de graduação em Odontologia. Brasil, 2000-2011

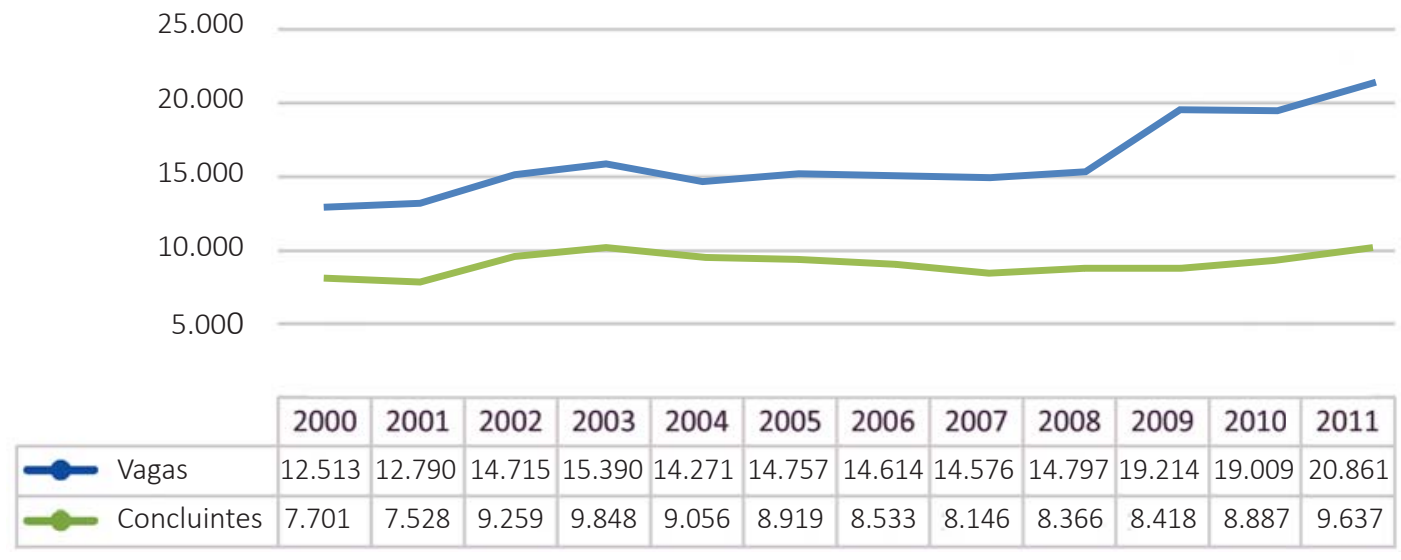

Fonte: INEP/MEC, SIGRAS/Estação de Trabalho IMS/UERJ, ObservaRH, 2012.

\section{2 | Programas de Formação de Médicos Especialistas}

Apesar do crescimento expressivo, ainda há uma distribuição bastante irregular das vagas dos programas de Residência Médica oferecidas pelas diversas regiões do país. Tal distribuição acompanha, na maioria dos casos, a distribuição dos vínculos dos médicos especialistas nas regiões, mostrando sempre uma grande concentração nas regiões de maior desenvolvimento econômico. As vagas credenciadas de Residência Médica estão concentradas de forma bastante semelhante à distribuição dos médicos em atividade mostrando a importância do mercado de trabalho como determinante do estabelecimento de programas e vagas.

Além disso, ao se analisar esta expansão nos últimos cinco anos, notase que ocorreu um aumento de vagas credenciadas de forma menos expressiva em áreas consideradas básicas (Clínica Médica, Cirurgia Geral, Pediatria, Ginecologia e Obstetrícia, Medicina Preventiva e Medicina de Família e Comunidade), revelando uma tendência na abertura de vagas em áreas mais especializadas. 
Atualmente, 35\% das vagas credenciadas são oferecidas por instituições estaduais, 30\% por instituições federais, $8 \%$ por instituições municipais e o restante (27\%) por instituições privadas. Considerando que a maioria das vagas em instituições privadas é custeada pelo poder público, é claro o predomínio do financiamento público na formação médica especializada.

\section{4 | PROFISSÕES E REGULAÇÃO PROFISSIONAL}

Neste capítulo, vamos tratar os desafios nos dois campos ou mundos: o do trabalho (das relações de trabalho) e o das profissões. Nos dois casos, parece ser necessário modernizar a legislação, produzir direito novo para abrigar dentro da legalidade os novos arranjos laborais distintos do trabalho assalariado, quer dizer as novas formas do trabalho de autônomos consorciados em redes, dos autônomos cooperados etc. (GIRARDI et al., 2010).

Dois desafios podem ser identificados aqui: dar legalidade a estas formas (quando lícitas, éticas, etc.) e estender o conjunto das proteções sociais, trabalhistas e previdenciárias a estas formas. O que ocorre hoje é que quem pode, os que têm renda suficiente extra consumo médio, compram estas "proteções" - planos de aposentadoria, saúde etc... no mercado; quem não pode, acumula, para além da instabilidade/labilidade da relação de trabalho uma desproteção completa contra os riscos do mercado de trabalho. A construção desse "amparo" para tais trabalhadores e profissionais implica no entanto em um novo pacto social para seu financiamento; um novo pacto de financiamento. Com o risco de simplificar demais, podemos dizer que o grande desafio para o futuro de uma sociedade democrática e inclusionista no campo do trabalho em geral é o das reformas necessárias para impedir a precariedade e a destruição física das pessoas que são os detentores da força de trabalho. No campo profissional, o grande desafio é transitar para um sistema de regulação desse tipo distinto de trabalho, de expertise, etc. que não confira a elas propriedade exclusiva sobre a expertise, transitar de um sistema elitista para um sistema que ao menos acomode as demandas de reconhecimento de práticas de trabalho não hegemônicas, acomodar as "profissões" menores ou num trocadilho, as "minorias profissionais" dentro de um sistema que as trate com equidade. Quando falamos de minorias profissionais queremos incluir também a "outra" saúde, que vem de outras culturas.

As profissões podem ser definidas em termos sociológicos por suas jurisdições de trabalho exclusivas, autonomia e capacidade de autorregulação. Elas são instituições sociais caracterizadas pela detenção de um patrimônio constituído por uma espécie de conhecimento complexo e abstrato, adquirido através de um longo processo de formação, geralmente nas universidades, e não acessível nas suas aplicações para o julgamento imediato pelo grande público. Os serviços que prestam 
são baseados nas relações de confiança com os clientes e na integridade moral dos seus membros. Devido a isto, ao contrário de outras empresas ou atividades trabalhistas, profissões são regulamentadas, em especial modos. A prevenção de riscos à vida, à integridade, à segurança, ao bem-estar dos clientes conduz a uma forma especial de regulação denominada autorregulação, ou seja, a regulação de pares, ao invés da regulação burocrática ou da regulação do mercado. As profissões detêm legalmente o que poderia ser definido como uma propriedade privada de tipo corporativa. No Brasil, como em muitos outros países, as profissões têm muito de suas vidas regulamentadas de tal maneira.

\subsection{O Modelo Brasileiro de Regulação Profissional}

A Constituição Federal (art.22, XVI) estabelece a competência exclusiva da União para legislar sobre a organização do sistema nacional de profissões. Ao Congresso Nacional (poder legislativo) compete analisar as reivindicações de regulamentação profissional depois de ouvido o Ministério que rege a área de trabalho, bem como os segmentos interessados da opinião pública, incluindo os profissionais para decidir se promulgam as leis ou não. Estas leis estabelecem basicamente o direito à prática e os âmbitos da prática de cada profissão. Elas também estabelecem as autoridades reguladoras de cada profissão (os Conselhos Profissionais, no caso de profissões autorreguladas). Cada profissão tem a sua própria e específica lei profissional.

As autoridades administrativas que participam do processo são as seguintes:

- Os ministérios substantivos que regem as suas áreas de trabalho;

- O Ministério do Trabalho e Emprego que decide sobre regulação ocupacional e trabalhista;

- O Ministério da Educação responsável pelas regras e credenciais para cada profissão.

O sistema universitário participa da educação profissional e fornece os diplomas que permitem aos graduados se registrarem em cada conselho profissional. E os conselhos profissionais registram e autorizam a prática pelos profissionais e são responsáveis pelo seu controle e disciplina. Exceto os advogados e veterinários, os demais profissionais não necessitam se submeter a um exame nacional para serem licenciados e autorizados para praticar sua profissão. É suficiente ter um diploma emitido pelas escolas profissionais e ser registrados e autorizados pelos conselhos.

O autogoverno das profissões e a atribuição a profissões autorreguladas de direitos legais exclusivos para o exercício da prática por meio de atos privados podem 
ser definidos como as características essenciais do modelo brasileiro de regulação profissional.

O modelo de autogoverno tem duas peças institucionais fundamentais: leis profissionais e conselhos profissionais:

As leis profissionais determinam:

- O escopo da prática profissional que é determinado por certas leis exclusivas;

- Pré-requisitos para a habilitação legal para exercer a prática, particularmente credenciais educacionais;

- Formas institucionais e competências de autoridades profissionais reguladoras.

Profissões autogovernadas são reguladas por seus respectivos conselhos. Existem 13 leis profissionais específicas para 14 profissões de saúde.

Os Conselhos Profissionais: são autarquias (instituições que possuem poder regulatório sobreseus membros e fazem parte do Estado; um braço descentralizado do governo; uma agência do Estado Brasileiro) com autoridade regulatória. Sua missão principal é de assegurar a proteção da população e a integridade profissional. Os conselhos:

- Registram e autorizam o profissional a exercer a prática;

- Determinam as regras e os regimentos, inclusive os códigos de ética que regulam a prática de seus membros;

- Fiscalizam e disciplinam a profissão.

Atualmente existem 13 Conselhos de Saúde Federais no Brasil e cada um deles possui aproximadamente 27 Conselhos Regionais (ou Estaduais).

Entre as profissões regulamentadas no Brasil:

- 116 profissões e ocupações são regulamentadas a nível nacional;

- 44 profissões regulamentadas são de nível superior;

- 37 profissões são regulamentadas por 28 Conselhos Profissionais;

- 14 profissões de saúde regulamentadas são de nível superior e são regidas por 13 Conselhos Profissionais de Saúde. 
Tabela 06. Profissões de saúde autorregulamentadas

\begin{tabular}{l|c|c}
\hline Conselho Profissional de Saúde & $\begin{array}{c}\text { Número de } \\
\text { profissionais } \\
\text { licenciados }\end{array}$ & $\begin{array}{c}\text { Existência de ocupações } \\
\text { subordinadas regulamentadas } \\
\text { pelo Conselho }\end{array}$ \\
\hline Médico & 331.146 & Não \\
\hline Dentista & 219.345 & Sim \\
\hline Psicólogos & 136.024 & Não \\
\hline Enfermeiro & 104.217 & Sim \\
\hline Assistentes Social & 96.209 & Não \\
\hline Profissionais de Educação Física & 164.230 & Não \\
\hline Farmacêutico & 104.098 & Sim \\
\hline Veterinário & 68.085 & Não \\
\hline Fisioterapeuta e Terapeuta ocupacional & 111.250 & Não \\
\hline Biólogo & 36.404 & Não \\
\hline Nutricionista & 50041 & Sim \\
\hline Fonoaudiólogo & 32.000 & Não \\
\hline
\end{tabular}

Fonte: Conselhos Profissionais, circa 2008

Atualmente existe em todo país uma grande demanda — uma verdadeira pletora - para regulação, desregulação ou re-regulação profissional de determinadas ocupações. Estas demandas partem de variadas fontes e chegam a representar interesses contrários:

- O público leigo reivindica envolvimento nos conselhos de profissionais de saúde, de forma a garantir que sua opinião seja devidamente representada no processo de regulamentação;

- Gestores de serviços de saúde reivindicam um sistema mais flexível que lhes permita combinar apropriadamente habilidades e competências multiprofissionais. Isto acarretaria uma prestação de cuidado à saúde mais eficaz para atender as demandas dos pacientes, levando em consideração a disponibilidade de recursos financeiros;

- As autoridades governamentais necessitam de uma maior coordenação sobre as profissões de saúde de forma a estabelecer políticas profissionais de acordo com suas responsabilidades governamentais que abrangem princípios de eficiência, equidade, praticidade e responsabilidade; 
- Profissionais de saúde e grupos ocupacionais possuem basicamente duas demandas referentes à regulamentação: expandir o direito exclusivo ou quase exclusivo do campo profissional e reconhecimento social.

É possível identificar uma dualidade nas reivindicações por regulação das profissões de saúde. Por um lado, as demandas para expandir os privilégios monopolísticos de profissões já estabilizadas e autorreguladas, como medicina, farmácia, odontologia, enfermagem, entre outras. Estas profissões reivindicam expansão de seus direitos a campos profissionais exclusivos. Por outro lado, as minorias profissionais, optométricos e parteiras, lutam por reconhecimento público e social.

Quatorze profissões não regulamentadas estão reivindicando junto ao Congresso Nacional formação superior e autorregulação, quatro destas são da área da saúde: acupuntura, optometria, musicoterapia e psicometria. Quarenta e sete ocupações de nível técnico também reivindicam regulamentação de suas atividades, dentre as quais 10 são da área da saúde: agentes comunitários de saúde, técnico de saúde bucal, técnico de nutrição, instrumentador cirúrgico, podólogos, oculista, entre outras.

As reivindicações da expansão da jurisdição profissional dizem respeito a:

- Autoridades educacionais para controlar o fluxo de entrada de profissionais no mercado de trabalho;

- Gestores de saúde, de forma a estabelecer o direito de definir padrões de prática, que permitam uma mistura de habilidades e competência, níveis hierárquicos de trabalho, etc;

- Autoridades e tomadores de decisões, para estabelecer o direito de participar nas definições de políticas de saúde;

- Profissões de saúde rivais, com o intuito de expandir seus direitos sob a profissão ao restringir a capacidade de o outro profissional praticar no campo disputado.

Essas pressões levaram o Ministério da Saúde a criar, em 2004, a Câmara de Regulação de Trabalho de Saúde (CRTS), de forma a abrir o diálogo entre o governo, os gestores de saúde, grupos profissionais e a população sobre a regulação profissional na área da saúde. Entre 2004 e 2008 o CRTS debateu projetos de Lei que foram submetidos ao Congresso Nacional por 11 ocupações profissionais. 


\section{5 | CONSIDERAÇÕES FINAIS}

Neste texto buscamos analisar e responder como está estruturada a oferta de formação e capacitação em saúde, bem como se esta oferta atende às necessidades atuais e futuras de desenvolvimento do sistema de saúde. Procuramos ainda revisar a estrutura do mercado de trabalho em saúde no Brasil e suas tendências.

Cerca de 15 mil médicos se formam anualmente no Brasil, mas há uma carência de profissionais para áreas de atenção básica. Faltam profissionais interessados em pediatria, geriatria, clínica e genética médica. Por outro lado, algumas especializações são bastante procuradas, como dermatologia, principalmente estética, oftalmologia, anestesia e cirurgia plástica. Nos últimos anos a pediatria é uma das especialidades com maior percentual de vagas não ocupadas nos programas de residência médica. O mesmo ocorre com as subespecialidades da pediatria (GIRARDI, 2010). Em relação à distribuição geográfica, não há um padrão uniforme. Algumas especialidades como a cirurgia torácica devem mesmo estar mais concentradas em regiões que estão no topo da pirâmide do sistema de saúde, enquanto as especialidades básicas, especialmente aquelas vinculadas à estratégia de saúde da família, devem ter um padrão de distribuição geográfica mais homogênea, mais universal.

Nesse sentido, há claramente uma tendência ao acirramento de desequilíbrios no mercado de trabalho em saúde e desigualdades tanto no que diz respeito às especialidades básicas no âmbito da APS quanto com relação à questão das especialidades clínicas, cirúrgicas e às especialidades de apoio (facility-based), mesmo porque sua distribuição deve ser diferenciada mesmo entre regiões, tamanho e grau de desenvolvimento dos municípios, etc.

Com base em dados dos censos populacionais e dos conselhos profissionais, mantida as tendências atuais de formação e mercado de trabalho, a projeção é de crescimento da oferta e da densidade per capita de médicos e enfermeiros, como mostram os gráficos 23 e 24. Os médicos tendem a crescer dos atuais 1.7 para um valor entre 2.3 e 3.5 por 1000 habitantes enquanto as enfermeiras passariam dos atuais 0.7 para um valor entre 2.4 e 4.0 por 1000 habitantes. 
Gráfico 23. Projeção da densidade per capita de médicos por 1000 habitantes, Brasil 1970-2030

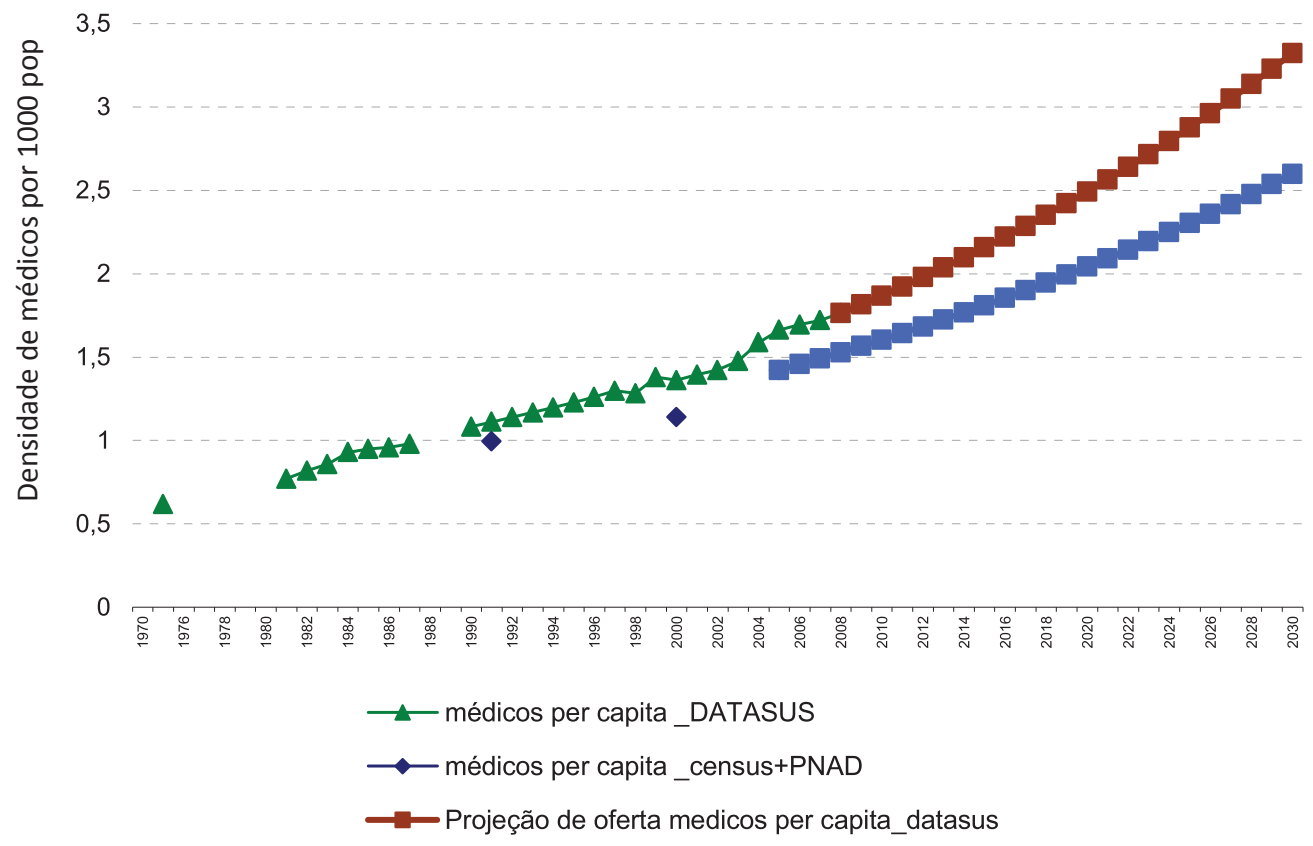

Gráfico 24. Projeção da densidade per capita de enfermeiro(a)s por 1000 habitantes, Brasil 19702030

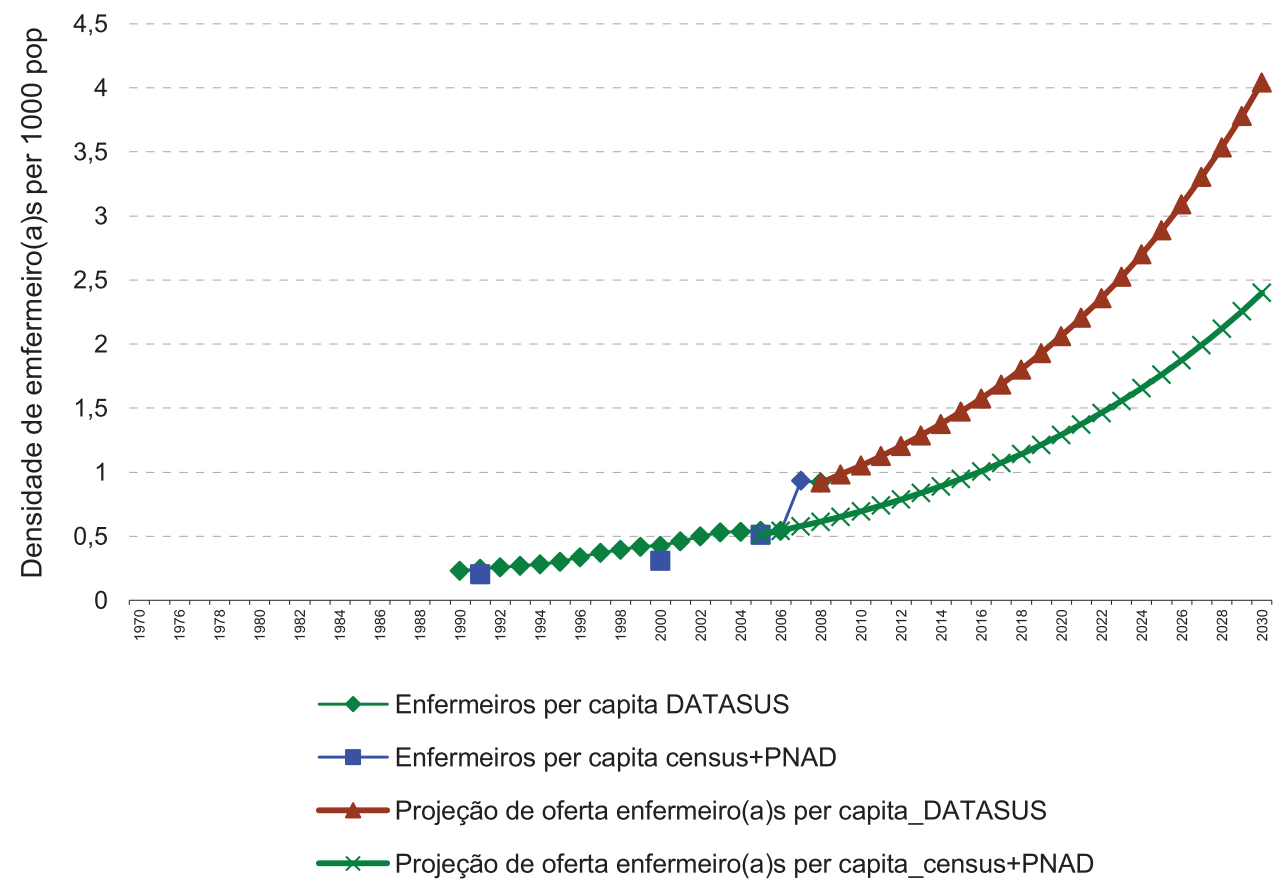


Com o envelhecimento da população brasileira, a demanda por geriatras tende a aumentar. Atualmente menos de 500 profissionais são titulados anualmente em geriatria e gerontologia. Juntamente com a deficiência no quadro, a distribuição também é irregular, uma vez que a maior parte dos profissionais está nas regiões Sudeste e Sul do país. O Norte é onde há maior carência, seguida pelo Nordeste e Centro-Oeste. No entanto, em 2030, serão 40 milhões de idosos, o que faz com que a geriatria seja essencial para a qualidade de vida de parte significativa da população brasileira. Nessa área da atenção ao idoso, o Brasil vai precisar capacitar também outros profissionais tais como fisioterapeuta, enfermeiros, odontogeriatras.

Registre-se que o Brasil é um dos poucos países que tem políticas intersetoriais para reformar graduação e residência, mas aparentemente, tais iniciativas ainda são incipientes diante da demanda.

O processo de regulação profissional, entendido como uma política pública é uma parte fundamental das políticas de saúde. Neste contexto, as demandas atuais e futuras dos grupos profissionais para regular suas atividades devem ser consideradas à luz de alguns princípios, como eficiência, equidade, praticidade e responsabilidade, em nome do interesse da população.

Dentre os principais determinantes que conduzem as novas exigências para regulamentação profissional podemos citar:

- A democratização do país, que tem permitido o surgimento de novos grupos profissionais que exigem, pelo menos, igualdade de tratamento e justiça do trabalho. A população que também reivindica participação em assuntos da esfera profissional.

- Avanços tecnológicos, que demandam trabalhos inter e multidisciplinar e transparência profissional.

- O desenvolvimento de novas formas de prestação de cuidados à saúde, como a Estratégia de Saúde da Família, que integra uma equipe multidisciplinar dentro de ambientes comunitários, requerendo o compartilhamento do escopo da prática.

Existe uma necessidade em alcançar um equilíbrio entre o interesse da população e a variedade de reivindicações por regulação profissional — eventualmente rivais - e conflitantes entre si.

Nesse sentido, a tendência em muitos países é de alterar o sistema que atribui direitos exclusivos de prática de forma a manter e combinar a autorregulação das profissões com o compartilhamento dos direitos de prática, ou seja, escopos de prática mais exclusivos ou mais compartilhados entre as profissões, o que pode implicar 
em variações significativas nas necessidades de médicos e enfermeiros, por exemplo, no futuro próximo, vários países já tomaram passos importantes nesta direção, com mecanismos que podem ser adaptados à situação brasileira.

Apesar das dificuldades de previsão sobre as políticas e elas valem inclusive para as projeções, particularmente no que diz respeito às possíveis mudanças na regulação profissional, a partir do que queremos para 2030, a implementação dessa agenda exige o planejamento de largo prazo. Por exemplo, mudanças nos marcos legais passam pelo Congresso, envolvem órgãos de controle (Ministério Públicos e Tribunal de Contas), o judiciário etc. Este tipo de ação, em geral, ultrapassa os tempos dos mandatos do executivo. Mas são ações que devem ser iniciadas já. Dentre as tendências futuras de regulação profissional se incluem:

- Revisão do quadro legal de regulamentação profissional;

- Revisão das formas institucionais e das estruturas de regulamentação profissional;

- Revisão dos escopos de prática das profissões regulamentadas e das novas que atualmente lutam por reconhecimento;

- Avaliação do modelo de autorregulação brasileira e, se for o caso, propor alternativas a este modelo. 


\section{6 | REFERÊNCIAS BIBLIOGRÁFICAS}

BRASIL. CONGRESSO NACIONAL. SICON. Sistema de Informações do Congresso Nacional. Prodasen, Senado Federal, Brasil, 2008.

BRASIL. MINISTÉRIO DA SAÚDE. Câmara de Regulação do Trabalho em Saúde, Brasil, 2008.

BRASIL. MINISTÉRIO DA SAÚDE. SECRETARIA EXECUTIVA. Mais saúde: direito de todos: 2008 2011 / Ministério da Saúde, Secretaria Executiva. - 4. Ed. — Brasília : Ministério da Saúde, 2010. 132 p. - (Série C. Projetos, Programas e Relatórios).

DAL POZ, MR, GUPTA, N, QUAIN, EE, SOUCAT, ALB. Handbook on Monitoring and Evaluation of Human Resources for Health, with special applications for low- and middle-income countries. ed 1. vol 1, 192 p. Geneva: World Health Organization.

DAL POZ, MR. Understanding women's contribution to the health workforce. Lancet, v.371, 641642, 2008.

DI PIETRO, MSZ. Direito Regulatório: Temas Polêmicos, Belo Horizonte: Forum, 2003.

DUSSAULT, G, FRONTEIRA, I, PRYTHERCH, H., DAL POZ, MR, NGOMA, D, LUNGUZI, J, WYSS, K. Scaling Up the Stock of Health Workers: a review. vols 1, p. 50. Geneva: ICHRN — International Centre for Human Resources in Nursing. 2009.

FREIDSON, E. Professionalism, the third logic: on the practice of knowledge. Chicago: The University of Chicago Press; 2001. 240p.

GAROUPA N. Regulation of Professions in the US and Europe: A Comparative Analysis. CEPR, London. April 2004 [http://law.bepress.com/alea/14th/art42].

GIRARDI S. N. (coord.); CARVALHO, CL; FARAH, JM; ARAUJO, JF; FERREIRA, JCL; MAAS, LWD; FERREIRA, LHS. Levantamento sobre a Desprecarização do trabalho em saúde no Brasil 1992 a 2008. Universidade Federal de Minas Gerais, Faculdade de Medicina, Núcleo de Educação em Saúde Coletiva, Estação de Pesquisa de Sinais de Mercado. Belo Horizonte, 2010.

GIRARDI, S. N. Aspectos do(s) mercado(s) de trabalho em saúde no Brasil: estrutura, dinâmica, conexões. In: SANTANA, P.; CASTRO, J. L. (Org.). Capacitação em desenvolvimento de recursos humanos de saúde. Natal: EDUFRN, p. 125-150, 1999.

GIRARDI, SN. (coord). Avaliação nacional da demanda de médicos especialistas percebida pelos gestores de saúde. NESCON. FM. UFMG. Belo Horizonte, Março 2009.

GIRARDI, SN. Demandas de mudança na regulação do Trabalho e das profissões de saúde nos EUA e Canadá. Informe de Pesquisa, OPAS, Washington DC, 1999.

GIRARDI, SN. Dilemas da Regulamentação Profissional em Saúde: Questões para um governo democrático e inclusionista. Revista Latinoamericana de Estudios del Trabajo, n. 15, 2002, pp 67-85, 2002.

GUPTA, N, DAL POZ, MR. Assessment of human resources for health using cross-national comparison of facility surveys in six countries. Human Resources for Health, v.7, 22, 2009 [http://www.biomedcentral.com/content/pdf/1478-4491-7-22.pdf]. 
HEALTH PROFESSIONS REGULATORY ADVISORY COUNCIL. Regulation of Health Professions in Ontario: New Directions. A Report to the Minister of Health and Long-Term Care on Regulatory Issues and Matters respecting Health Care Practitioners, Patients and Clients. 2006 [http://www. hprac.org/en/reports/resources/New_Directions_April_2006_EN.pdf].

KINFU, Y, DAL POZ, MR, MERCER, HS, EVANS, DB. The health worker shortage in Africa: are enough physicians and nurses being trained? Bulletin of the World Health Organization, v.87, 225-230, 2009.

MOREIRA, V. Auto-regulação profissional e Administração Pública. Coimbra: Almedinam. 1997.

NOGUEIRA, RP. A saúde do avesso. Natal: Seminare Editora, 2003, 260pp.

ONTARIO. HEALTH PROFESSIONS LEGISLATION REVIEW. Striking a new balance: a blueprint for the regulation of Ontario's health professions: recommendations of the Health Professions Legislation Review. The Review, 1989. 349 p. Pew Health Professions Commission. Critical challenges: Revitalizing the health professions for the twenty-first century. San Francisco: UCSF Center for the Health Professions. 1995 [http://www.futurehealth.ucsf.edu/Content/29/1995-12_ Critical_Challenges_Revitalizing_the_Health_Professions_for_the_Twenty-First_Century.pdf].

PIERANTONI, CR e VIANNA, AL (Orgs.). Educação e Saúde. São Paulo — SP: Hucitec, 2010. 239p.

PIERANTONI, CR; HADDAD, AE; RISTOFF, D; XAVIER, IM; GIOLO, J; SILVA, LB (Orgs.). A Trajetória dos Cursos de Graduação na Saúde 1991 - 2004. Brasília: Ministério da Saúde, 2006. v. 1. 531 p.

PIERANTONI, CR; FRANÇA, T; MAGNAGO, C; NASCIMENTO, DN; MIRANDA, RG. Graduações em Saúde no Brasil: 2000 - 2010. 1. Rio de Janeiro: CEPESC, 2012. v. 1. 228p.

PIERANTONI, CR; MACHADO, MH; FERREIRA, JR; ABRANZON, M; CAMPOS, E (Organizadores). Trabalho e Educação em Saúde no Mercosul. Brasília-DF: Europa, 2008. 228 p.

PIERANTONI, CR; VARELLA, TC; FRANÇA, TA. A Formação Médica: capacidade regulatória de estados nacionais e demanda dos Sistemas de Saúde. Cadernos RH Saúde, Brasília, v. 3, n. 1, p. 91-102, 2006.

PIERANTONI, CR; VARELLA, TC; SANTOS, MR; FRANÇA, T; GARCIA, AC P. Gestão do Trabalho e da Educação em Saúde: recursos humanos em duas décadas do SUS. Physis. Revista de Saúde Coletiva, v. 18, p. 685-704, 2008.

SCHEFFLER, RM, LIU, JX, KINFU, Y, DAL POZ, MR. Forecasting the global shortage of physicians: an economic- and needs-based approach. Bulletin of the World Health Organization, v.86, 516523, 2008.

SOUSA, A ; DAL POZ, MR ; HILL, K. Sub-national assessment of inequality trends in neonatal and child mortality in Brazil. International Journal of Equity in Health, v. 9, p. 21, 2010. [http://www. equityhealthj.com/content/9/1/21].

VARELLA, TC.; PIERANTONI, CR. Mercado de trabalho: revendo conceitos e aproximando o campo da saúde. A década de 90 em destaque. Physis. Revista de Saúde Coletiva, v. 18, p. 521544, 2008.

WOLFSON, AD., TREBILCOCK, MJ and TUOHY, CJ. Regulating the professions: A theoretical framework. In ROTTENBERG, S (Ed.), Occupational licensure and regulation. Washington, DC: American Enterprise Institute for Public Policy Research. 1980. 


\begin{tabular}{|c|c|c|c|c|c|c|c|c|c|c|c|c|c|c|c|c|c|c|c|c|c|c|c|c|c|}
\hline 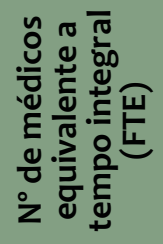 & ஸ̃ & 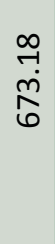 & $\begin{array}{l}\stackrel{P}{1} \\
\stackrel{9}{9} \\
\stackrel{9}{-}\end{array}$ & 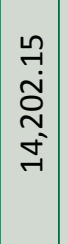 & 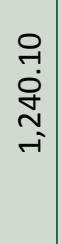 & 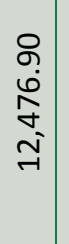 & $\begin{array}{c}m \\
m \\
o \\
o \\
N \\
N\end{array}$ & $\begin{array}{l}\stackrel{n}{N} \\
\tilde{\vartheta} \\
\mathscr{\emptyset}\end{array}$ & 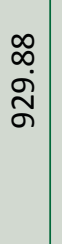 & 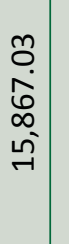 & $\begin{array}{c}0 \\
m \\
m \\
\infty \\
\stackrel{-}{-i}\end{array}$ & 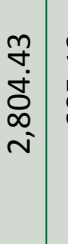 & 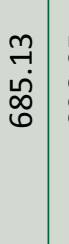 & $\begin{array}{l}\qquad 0 \\
\circ \\
\grave{g}\end{array}$ & $\begin{array}{l}m \\
0 \\
\dot{0} \\
m \\
m \\
b^{\prime}\end{array}$ & 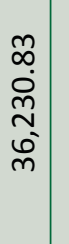 & $\begin{array}{l}\text { ñ } \\
\text { तं } \\
\text { مे } \\
\text { ه }\end{array}$ & 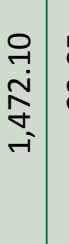 & $\begin{array}{l}\stackrel{2}{\circ} \\
\stackrel{\sim}{N}\end{array}$ & 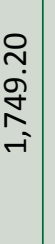 & $\begin{array}{l}\stackrel{n}{m} \\
m \\
m\end{array}$ & 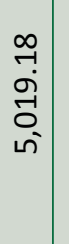 & $\begin{array}{l}\stackrel{\sim}{N} \\
\stackrel{D}{n} \\
\stackrel{n}{n}\end{array}$ & 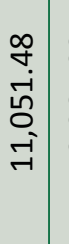 & \\
\hline مَّ & $\begin{array}{l}\text { 윰 } \\
\text { N } \\
\text { N }\end{array}$ & $\begin{array}{l}\hat{\sigma} \\
\text { స్ } \\
\text { స్ }\end{array}$ & $\begin{array}{l}\infty \\
\infty \\
\stackrel{N}{N} \\
\text { nn }\end{array}$ & \begin{tabular}{l|}
0 \\
0 \\
0 \\
0 \\
0 \\
0
\end{tabular} & 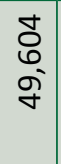 & $\begin{array}{l}0 \\
\hat{0} \\
9 \\
\sigma \\
\sigma\end{array}$ & $\begin{array}{l}m \\
\vec{y} \\
8 \\
8\end{array}$ & $\begin{array}{l}\text { సે } \\
\hat{\omega} \\
\tilde{\omega}^{-}\end{array}$ & 望 & $\begin{array}{l}\overrightarrow{1} \\
0 \\
0 \\
\tilde{\tilde{N}} \\
0\end{array}$ & $\begin{array}{l}\tilde{m} \\
\tilde{m} \\
\tilde{n} \\
\end{array}$ & 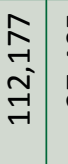 & 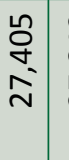 & $\mathcal{Z}$ & 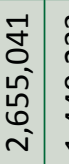 & $\begin{array}{l}\stackrel{n}{N} \\
\text { à } \\
\stackrel{g}{+} \\
-1\end{array}$ & $\overrightarrow{6}$ & $\begin{array}{l}\$ \\
\infty \\
\infty \\
\infty \\
\infty^{-}\end{array}$ & $\begin{array}{l}8 \\
8 \\
i \\
\infty \\
\infty\end{array}$ & $\begin{array}{l}\infty \\
\varnothing \\
\varnothing\end{array}$ & $-i$ & 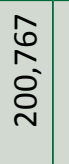 & 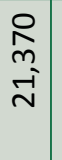 & $\stackrel{7}{ป}$ & \\
\hline
\end{tabular}

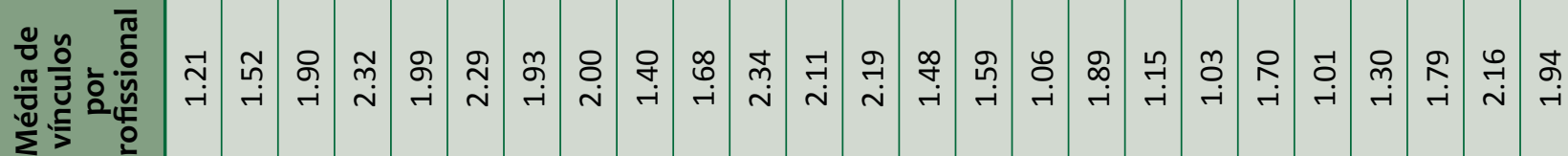

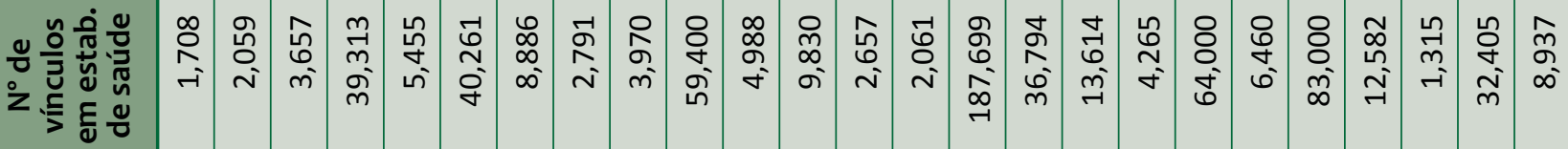

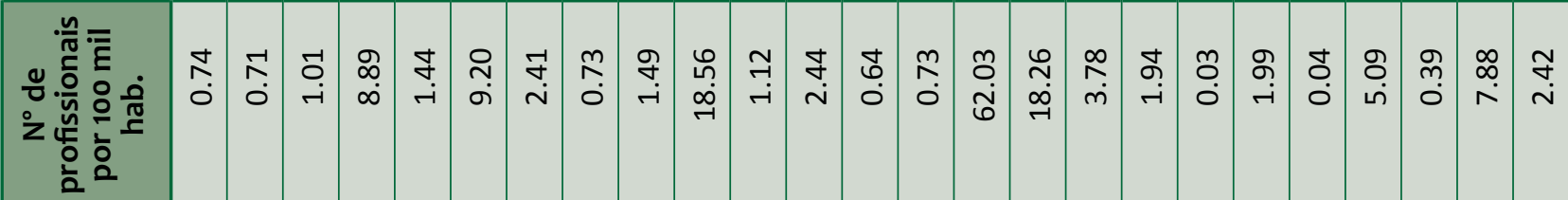

뜽 유

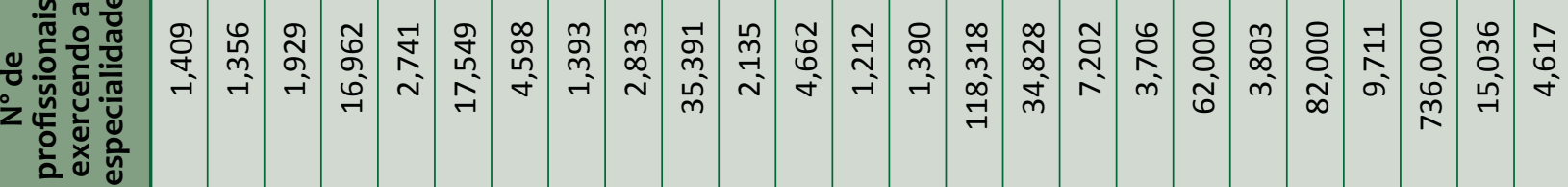

กั

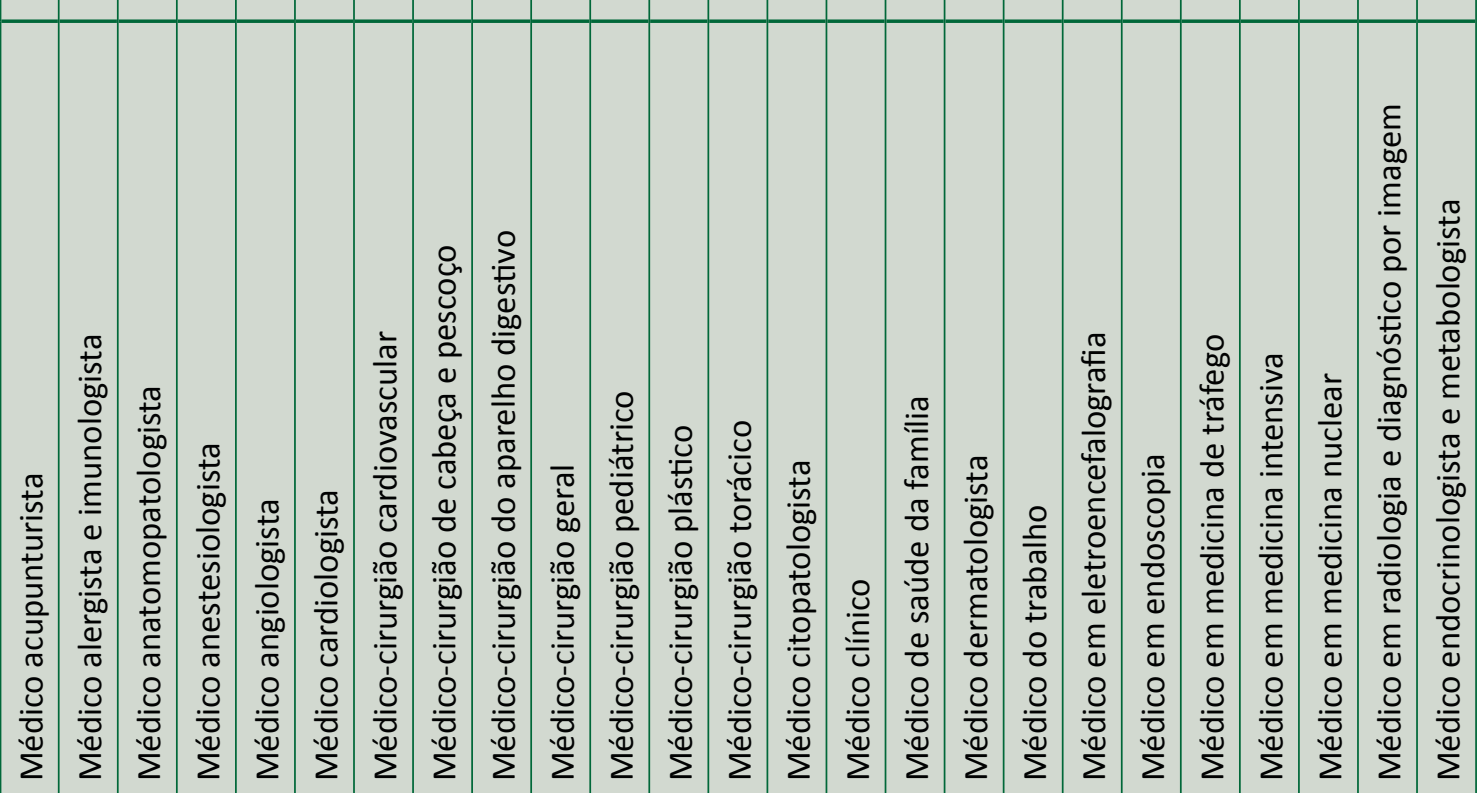




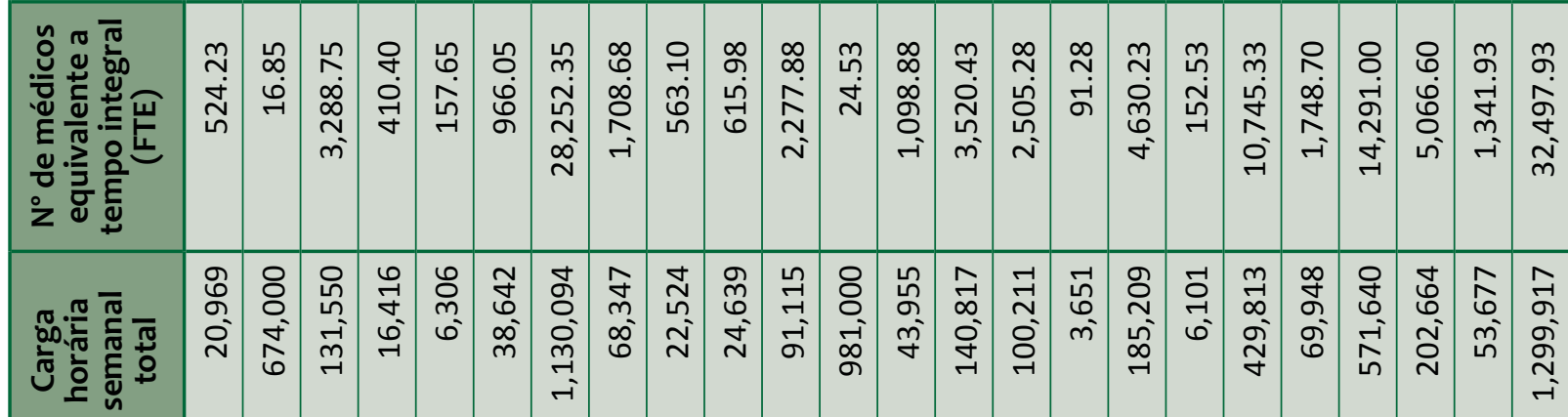

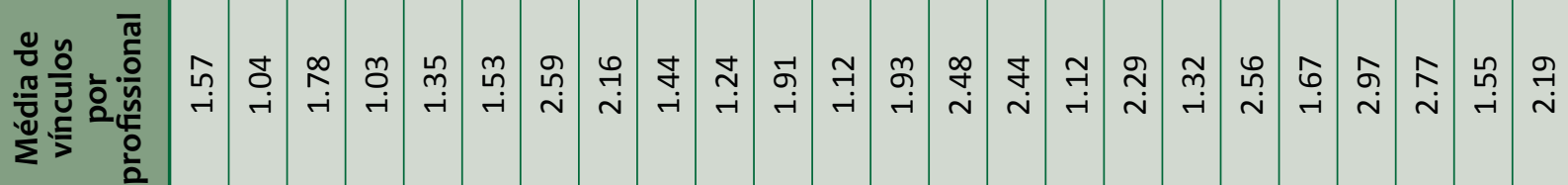

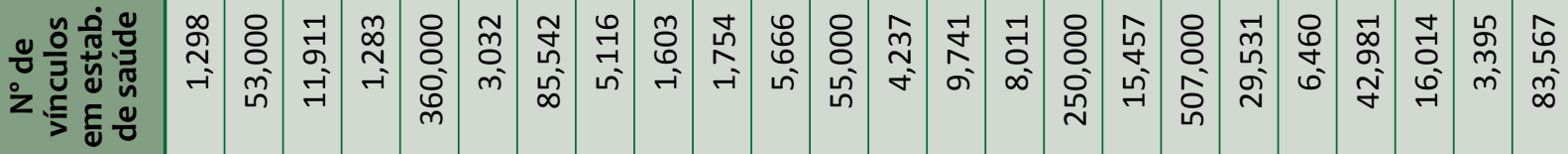

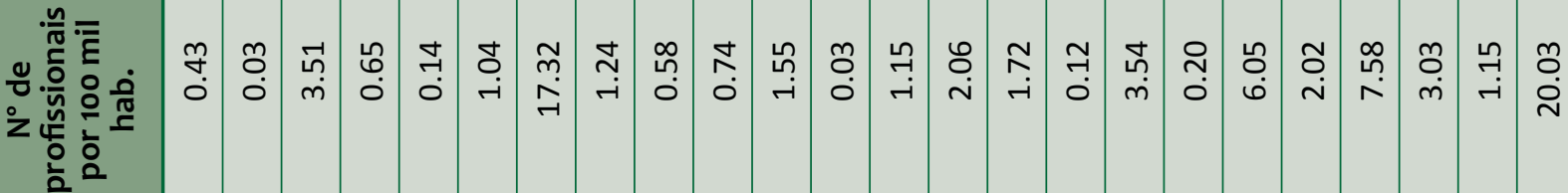

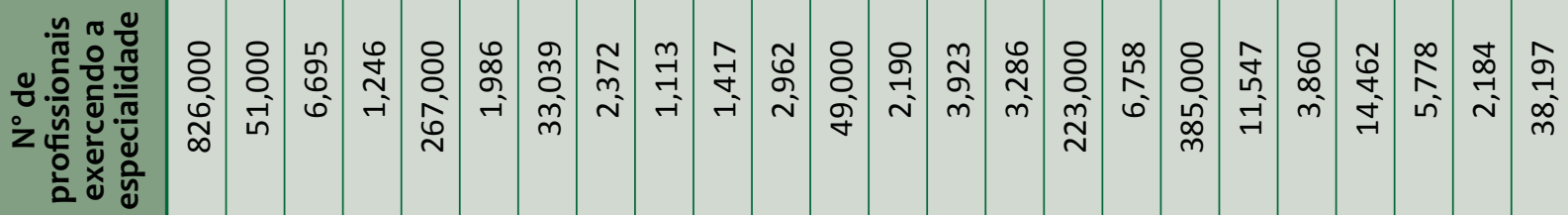

姺

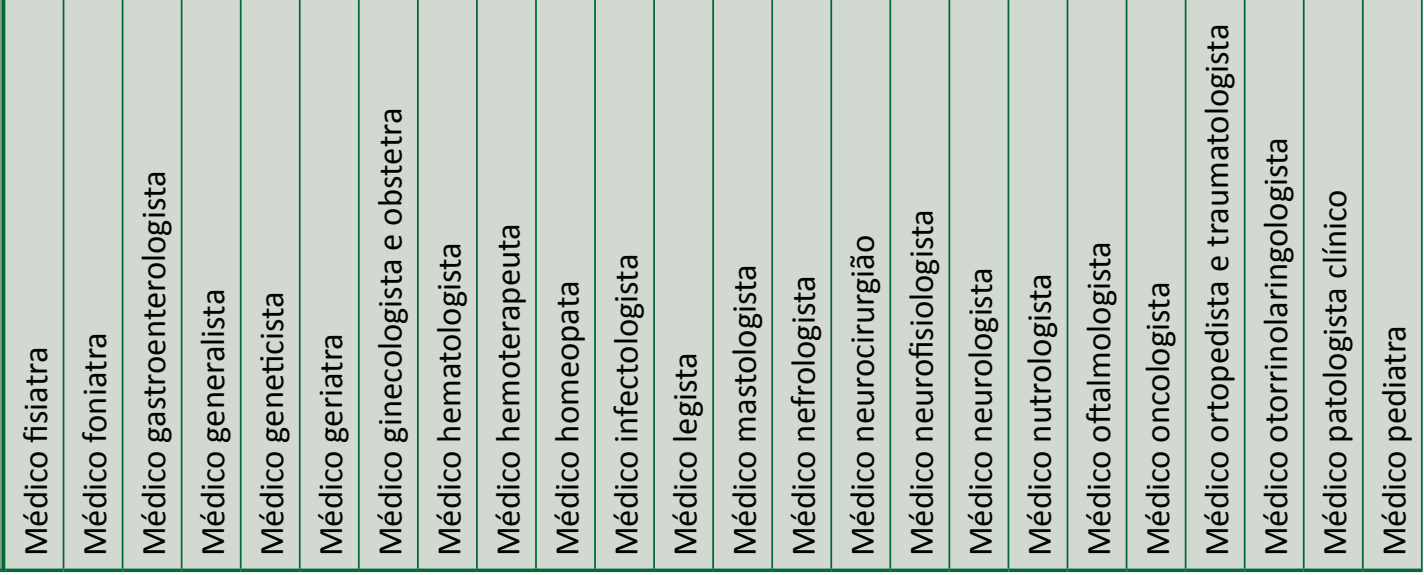




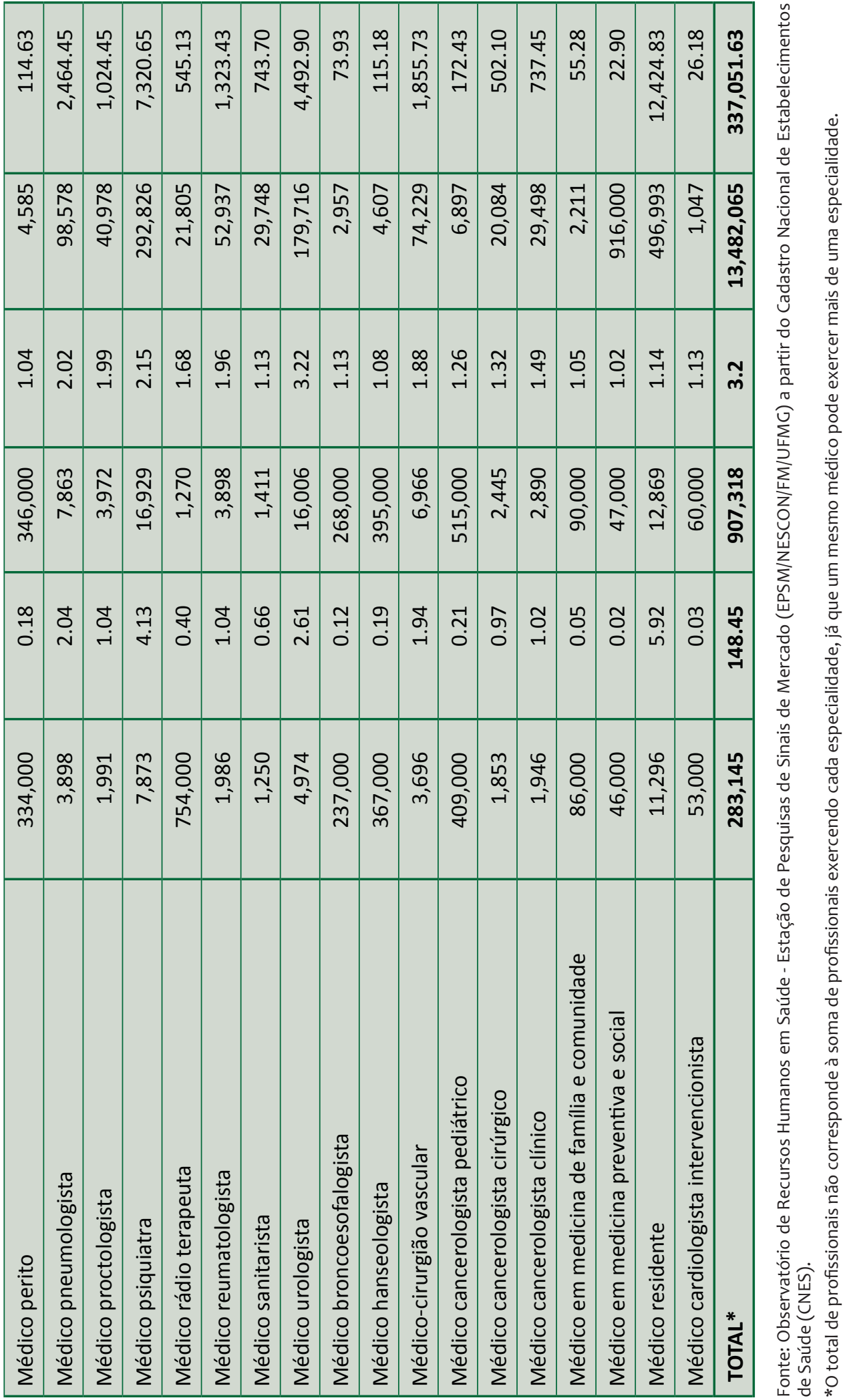

